\title{
Investigating the chronostratigraphy of prominent palaeosols in Lower Austria using post-IR IRSL dating
}

\author{
Christine Thiel, Jan-Pieter Buylaert, Andrew S. Murray, Birgit Terhorst, Sumiko Tsukamoto, Manfred Frechen, Tobias Sprafke
}

Abstract:

\begin{abstract}
The age of most Lower Austria loess deposits is unknown; this is especially true for Middle Pleistocene loess because there is no generally applicable dating method available. Recently it has been shown that infrared stimulated luminescence (IRSL) signals measured at elevated temperatures after an infrared (IR) stimulation are more stable than the standard IRSL signal measured at $50^{\circ} \mathrm{C}$. These signals offer new opportunities to extend the datable age range by minimising or circumventing the undesirable anomalous fading correction. In this study we apply, for the first time, two post-IR IRSL single-aliquot regenerative (SAR) dating protocols to polymineral fine-grain samples from three loess/palaeosol sequences in Lower Austria. The luminescence characteristics and ages derived from these protocols are compared with the IRSL results obtained at $50^{\circ} \mathrm{C}$. Recycling ratios, recuperation and dose recovery tests show that these protocols are applicable to the loess under investigation. Fading rates for the post-IR IRSL signals are significantly smaller than for the IRSL at $50^{\circ} \mathrm{C}$; the differences in fading rates between post-IR IRSL at $225^{\circ} \mathrm{C}$ and post-IR IRSL at $290^{\circ} \mathrm{C}$ are less obvious. Significant fading corrections are needed for the ages derived from the IRSL signal at $50^{\circ} \mathrm{C}$. From our study we conclude that the fading corrected post-IR IRSL at $225^{\circ} \mathrm{C}$ and the fading uncorrected post-IR IRSL at $290^{\circ} \mathrm{C}$ provide the best age estimates; we prefer the latter because no fading correction is apparently needed. Our data strongly suggest that the pedocomplex 'Paudorfer Bodenbildung' developed during marine isotope stage (MIS) 5, whereas the pedocomplex 'Göttweiger Verlehmungszone' is significantly older ( $\geq 350 \mathrm{ka}$ ) than has been suggested in former studies.
\end{abstract}

[Untersuchungen zur Chronostratographie von bekannten Paläoböden in Niederösterreich mittels post-IR IRSL-Datierung]

Kurzfassung:

Das Alter der meisten Lössablagerungen in Niederösterreich ist nicht bekannt. Das gilt insbesondere für mittelpleistozänen Löss, weil es keine allgemein anwendbare und akzeptierte Datierungsmethode für diesen Zeitraum gibt. Vor kurzem wurde gezeigt, dass infrarot-stimulierte Lumineszenz-(IRSL)-Signale, die bei erhöhten Temperaturen nach einer IR-Stimulation gemessen werden, wesentlich stabiler sind als standardmäßig bei $50^{\circ} \mathrm{C}$ gemessene IRSL-Signale. Diese Signale eröffnen die Möglichkeit, die datierbare Altersgrenze zu erweitern, indem der anomale Signalverlust (Fading) minimiert oder gar komplett umgangen wird. In dieser Arbeit wenden wir erstmalig zwei post-IR IRSL Single-Aliquot (SAR)-Datierungsprotokolle für polymineralische Feinkornextrakte von drei unterschiedlichen Löss-Paläoboden-Sequenzen aus Niederösterreich an. Die Lumineszenzcharakteristika und Alter der unterschiedlichen Protokolle werden mit denen von Messungen bei $50^{\circ} \mathrm{C}$ verglichen. Standardisierte Tests (recycling ratios, recuperation und dose recovery) zeigen, dass die Protokolle auf den untersuchten Löss anwendbar sind. Die FadingRaten für die post-IR IRSL-Signale sind wesentlich geringer als für IRSL bei $50^{\circ} \mathrm{C}$, während die Unterschiede in gemessenen Fading-Raten für post-IR IRSL bei $225^{\circ} \mathrm{C}$ und post-IR IRSL bei $290^{\circ} \mathrm{C}$ weniger offensichtlich sind. Signifikante Fading-Korrekturen für IRSL bei $50^{\circ} \mathrm{C}$ sind notwendig. Basierend auf unseren Daten schlussfolgern wir, dass die fading-korrigierten post-IR IRSL Alter bei $225^{\circ} \mathrm{C}$ und die nicht-korrigierten post-IR IRSL Alter bei $290^{\circ} \mathrm{C}$ die besten Altersabschätzungen für die untersuchten Sedimente liefern. Wir bevorzugen die letztgenannten Alter, weil keine Abhängigkeit zu Fading-Korrekturen besteht. Unsere Daten weisen darauf hin, dass die Paudorfer Bodenbildung sich während MIS 5 entwickelte, während die Göttweiger Verlehmungszone wesentlich älter ist ( $\geq 350 \mathrm{ka}$ ) als in den meisten vorangegangen Studien angenommen wurde.

Keywords: post-IR IRSL; fading; loess; Middle Pleistocene; Lower Austria

Addresses of authors: C. Thiel ${ }^{*}$, S. Tsukamoto, M. Frechen, Section S3: Geochronology and Isotope Hydrology, Leibniz Institute for Applied Geophysics, Stilleweg 2, 30655 Hannover, Germany. E-Mail: christine.thiel@liag-hannover.de; sumiko.tsukamto@liag-hannover. de; manfred.frechen@liag-hannover.de; C. Thiel, J.-P. Buylaert, A. S. Murray, Nordic Laboratory for Luminescence Dating, Department of Earth Sciences, Aarhus University, Risø DTU, 4000 Roskilde, Denmark. E-Mail: jabu@risoe.dtu.dk; anmu@ risoe.dtu.dk; J.-P. Buylaert, Radiation Research Division, National Laboratory for Sustainable Energy, Risø DTU, 4000 Roskilde, Denmark; B. Terhorst, T. Sprafke, Institute of Geography, Department for Physical Geography, University of Würzburg, Am Hubland, 97074 Würzburg, Germany. E-Mail: birgit.terhorst@uni-wuerzburg.de; t.sprafke@gmx.de. *corresponding author

\section{Introduction}

Loess/palaeosol sequences contain detailed archives of terrestrial palaeoenvironmental changes and landscape evolution. Unfortunately, most loess sequences lack a reliable absolute chronology and hence these changes are difficult to constrain in time. Especially for Middle Pleistocene loess deposits, geochronological information is scarce because there is, as yet, no generally applicable and reliable instrumental dating method which can be used for this age range.
Luminescence dating has proved to be a useful tool to date loess deposits (RoBERTs, 2008), not only because of the wide age range covered by this technique (from a few years to, theoretically, several hundred thousand years; AITKEN, 1998) but also because of the long sub-aerial transport of the particles which make up loess; this is confidently expected to have bleached any luminescence signal prior to deposition. Loess is also made up almost entirely of quartz and feldspar, both of which are suitable dosimeters for luminescence dating. The main drawback in the optically 


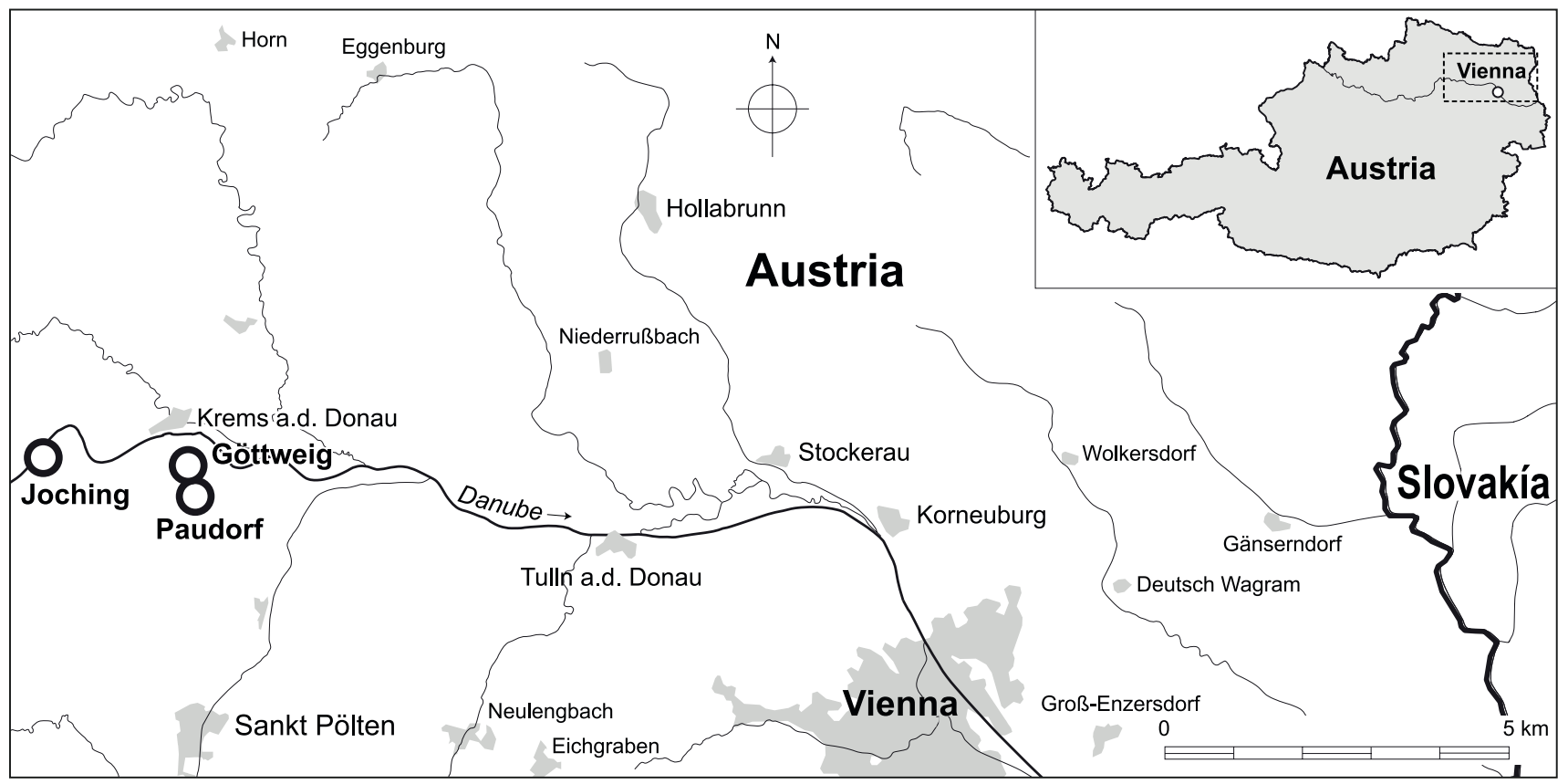

Fig. 1: Map of the study area, showing the locations of Göttweig (Furth and Aigen), Paudorf, and foching.

Abb. 1: Karte des Untersuchungsgebietes mit den Lokalitäten Göttweig (Furth und Aigen), Paudorf und foching.

stimulated luminescence (OSL) dating of quartz extracted from loess is the low saturation level of $\sim 200 \mathrm{~Gy}$; this is equivalent to $\sim 50-70 \mathrm{ka}$ assuming a dose rate of between 3 and 4 Gy/ka (typical for loess, e.g. Frechen et al., 1997; Novothny et al., 2002, 2009; WANG et al., 2006; BuylaERT et al., 2007; LAI et al., 2010; Thiel et al., 2011a, b). In contrast, feldspar infrared stimulated luminescence (IRSL) signals have a much higher saturation dose ( 1500-2000 Gy; equivalent to $\sim 500-700 \mathrm{ka}$ ) but, on the other hand, most feldspars suffer from athermal signal loss, referred to as anomalous fading (WINTLE, 1973; Spooner, 1994). Because of this phenomenon, IRSL ages tend to significantly underestimate the depositional age. HuntLey \& LAMothe (2001) have presented a model that can be used to correct the age underestimation, but these corrections are theoretically only applicable to the linear part of the growth curve, i.e. to young samples. Approaches which allow for correction beyond the linear region have been proposed by LAмотнE et al. (2003) and KARS et al. (2008); in principle these models can be used for older material (in case of loess $>50 \mathrm{ka}$ ), but there is little or no testing of these models available in the literature. Although fading corrections can give apparently accurate ages (HuntLEy \& LAMOTHE, 2001; BuylAERT et al., 2011) it seems more advisable to make use of IRSL signals that show less or no fading (THIEL et al., 2011a, submitted) because all correction models involve untestable assumptions, including that the fading rate observed on a laboratory timescale is relevant to geological time. In addition, there are examples where feldspar IRSL ages underestimate when compared with independent age control, even after fading correction (e.g. WALLINGA et al., 2007).

Recent developments in luminescence dating offer the potential to circumvent the problem of anomalous fading, and thus to extend the reliable dating range to the Middle Pleistocene (126 to $781 \mathrm{ka}$; HEAD et al., 2008). The postIR IRSL signal (IR stimulation at $50^{\circ} \mathrm{C}$ and subsequent IRSL measurement at $225^{\circ} \mathrm{C}$, blue detection; THOMSEN et al., 2008) seems to have great potential; in the laboratory, this signal fades more slowly than conventional IRSL measured at $50^{\circ} \mathrm{C}$. Buylaert et al. (2009) tested the applicability of this post-IR IRSL signal to dating sand-sized potassium feldspar grains; the fading rate of the post-IR IRSL signal was two times smaller than the one of the IRSL signal measured at $50^{\circ} \mathrm{C}$. Thiel et al. (2011a) used a preheat of $320^{\circ} \mathrm{C}(60 \mathrm{~s})$, IR stimulation at $50^{\circ} \mathrm{C}(200 \mathrm{~s})$ and subsequent post-IR IR stimulation at $290^{\circ} \mathrm{C}(200 \mathrm{~s})$ for polymineral fine grains $(4-11 \mu \mathrm{m})$. They measured the natural signal and dose response curve of a sample from below the Brunhes/Matuyama boundary $(\sim 780 \mathrm{ka}$, expected natural dose $>2700 \mathrm{~Gy})$, and found the natural signal in saturation on the laboratory regenerated growth curve; from that they concluded that for their samples they were unable to detect any evidence for anomalous fading in the field using post-IR IRSL at $290^{\circ} \mathrm{C}$.

Even though post-IR IRSL dating in its different forms has now been applied in several studies (BUyLAERT et al., 2009; Thiel et al., 2010, 2011a, accepted; ReimanN et al., 2011) no study has compared the performance of the two different post-IR IRSL dating protocols now in use. In this paper we compare the ages derived from the IR signal at $50^{\circ} \mathrm{C}$ and two post-IR IRSL signals (post-IR IR stimulation at $225^{\circ} \mathrm{C}$, BuYlaERT et al., 2009; post-IR IR stimulation at $290^{\circ} \mathrm{C}$, Thiel et al., 2011a) for three loess/palaeosol sequences in Lower Austria: i) Joching, ii) Paudorf, and iii) Göttweig. These sites have a long scientific history, starting with the investigations of BAYER (1927) and GöTZINGER (1936). Nevertheless the ages of the pedocomplexes 'Paudorfer Bodenbildung' and 'Göttweiger Verlehmungszone' are still controversial (FINK, 1976; Noll et al., 1994; Zöller et al., 1994; SMOLÍ́KovÁ et al., 1994) due to discontinuities as the result of intensive erosional phases (cf. HAVLIČEK et al., 1998), and illustrate the need for a more reliable numerical dating method. We first demonstrate that our measurement pro- 


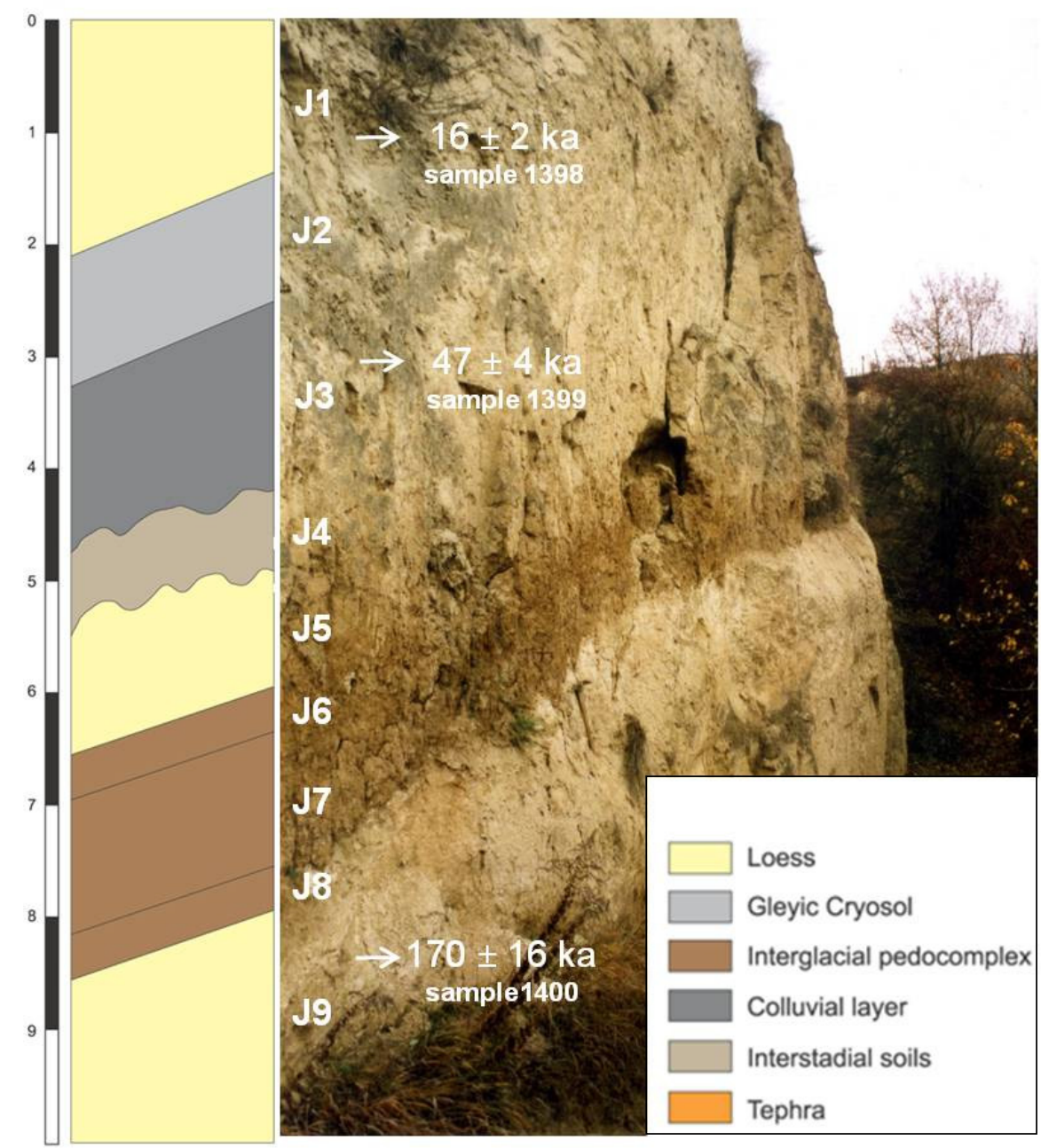

Fig. 2: Photograph and simplified sketch of the loess/palaeosol sequences at foching. The luminescence ages presented are uncorrected post-IR IRSL ages at $290^{\circ} \mathrm{C}$. For details on the material composition, sampling depths and dating see text. (Photo: Reinhard Roetzel)

Abb. 2: Fotographie und vereinfachte Profilzeichung der Löss-Paläoboden-Sequenz in foching. Die präsentierten Lumineszenzalter sind nichtkorrigierte post-IR IRSL Alter bei $290^{\circ} \mathrm{C}$. Siehe Text für detaillierte Informationen zu Material, Probentiefe und Datierung. (Foto: Reinhard Roetzel) tocols are applicable to these samples, by examining recuperation, recycling ratios and the ability of these protocols to measure a known dose given in the laboratory. Subsequently the luminescence characteristics, the equivalent doses and laboratory fading rates for the various signals are compared and the derived ages (corrected and uncorrected) are discussed in terms of their reliability. Finally, the most reliable set of IRSL ages is used to unravel the chronostratigraphy of the prominent palaeosols in Lower Austria.

\section{Site descriptions and sampling}

The loess/palaeosol sequences investigated in this study are located in the Kremser Feld in Lower Austria (Fig. 1); this region is covered by up to $30 \mathrm{~m}$ of loess deposits. Three sites exhibiting the prominent palaeosols 'Paudorfer Bodenbildung' and 'Göttweiger Verlehmungszone' were investigated; samples for luminescence dating were taken by hammering metal tubes into the freshly cleaned profile. Samples for dosimetry measurements $(\sim 1000 \mathrm{~g})$ were taken from immediately around the luminescence samples.

\subsection{Joching}

The village of Joching is located on the left bank of the Danube (Fig. 1) and is the furthest upstream of our sites. The loess/palaeosol sequence has a total thickness of about 10 $\mathrm{m}$, with at least two distinct palaeosols (Fig. 2). Below silty yellowish-brown loess (unit J1) a zone of Cryosol horizons (unit J2) is underlain by stratified loamy pellet sands ('Bröckelsande'; unit J3) of up to $4 \mathrm{~m}$ thickness. These sands cover a palaeosol horizon with interstadial intensity (J4). About 1.0 $\mathrm{m}$ of silty yellowish-brown loess rich in secondary carbonates and with few mollusc fragments (unit J5) is exposed below this soil. The loess is underlain by a pedocomplex (units J6-8) which intensity implies interglacial conditions. Loess (unit J9) is exposed below this pedocomplex.

At this site three luminescence samples were taken (Fig. 2). Sample 1398 was taken from the loess unit J1 1.3 m below top ground surface. The 'Bröckelsand' (unit J3) was sampled (sample 1399) $0.2 \mathrm{~m}$ below the Cryosol complex (unit J2), and sample 1400 was taken in the loess unit J9 $0.7 \mathrm{~m}$ below the pedocomplex, i.e. $\sim 8.3 \mathrm{~m}$ below top ground surface.

\subsection{Paudorf}

The village of Paudorf is located on a right bank tributary of the Danube. The loess/palaeosol sequence is exposed in a former brickyard and is the type locality of the 'Paudorfer Bodenbildung' sensu GöTzINGER (1936). The outcrop, last described by Fink (1976) and thermoluminescence (TL) dated by ZöLler et al. (1994) and Noll et al. (1994), is about $9.5 \mathrm{~m}$ thick (Fig. 3). At least two well-developed pedocomplexes are preserved at this site; the uppermost soil complex is the prominent 'Paudorfer Bodenbildung' (Fig. 3). 


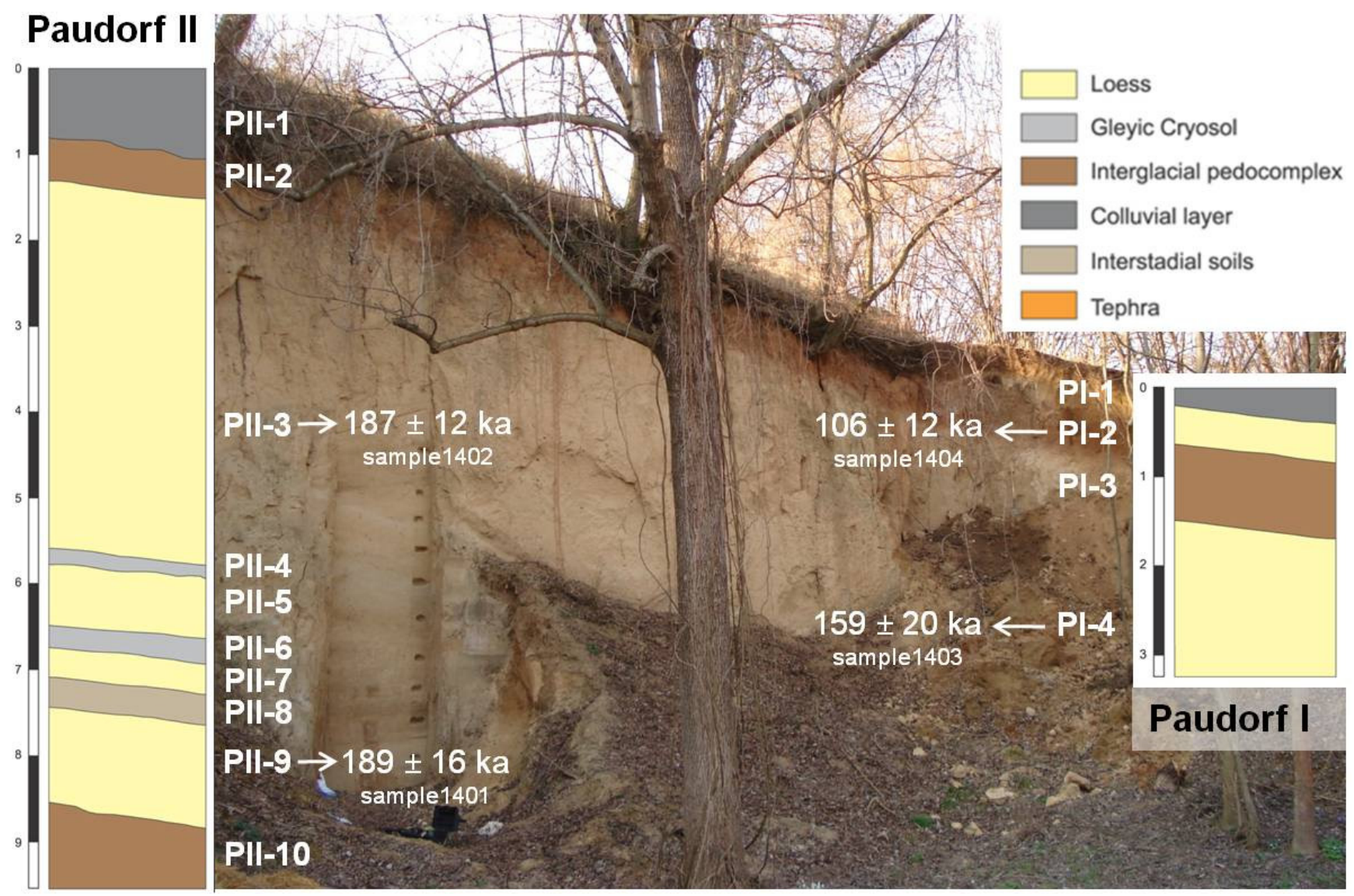

Fig. 3: Photograph and simplified sketches of the loess/palaeosol sequence at Paudorf. The presented ages are based on post-IR IRSL dating at $290^{\circ} \mathrm{C}$ (except sample 1403, for which corrected post-IR IRSL at $225^{\circ} \mathrm{C}$ was used). For details on the material composition, sampling depths and dating see text.

Abb. 3: Fotographie und vereinfachte Profilzeichnungen der Löss-Paläoboden-Sequenz in Paudorf. Die präsentierten Lumineszenzalter sind nicht-korrigierte post-IR IRSL Alter bei $290^{\circ} \mathrm{C}$ (bis auf Probe 1403, für die das korrigierte post-IR IRSL Alter bei $225^{\circ} \mathrm{C}$ genommen werden musste). Siehe Text für detaillierte Informationen zu Material, Probentiefe und Datierung.

The luminescence sampling points are shown in Figure 3; two adjacent profiles were sampled (Paudorf I and II). The uppermost sample 1404 was taken in loess (unit PI-2) $0.3 \mathrm{~m}$ above the 'Paudorfer Bodenbildung' (unit PI-3), which is here developed as a reddish-brown, clay-rich palaeosol with crotovina. The loess unit PI-4 below the 'Paudorfer Bodenbildung', was sampled $2.9 \mathrm{~m}$ below top ground surface (sample 1403).

In profile Paudorf II, the $4 \mathrm{~m}$ thick loess (PII-3) was sampled below the 'Paudorfer Bodenbildung' at a depth of $4.2 \mathrm{~m}$ (sample 1402); because of induration, this sample had to be taken as a block. The loess deposit is underlain by alternating Cryosol and loess horizons (PII-4 to PII-7). In its lower parts a weak brownish palaeosol is exposed (PII-8). A loess layer (PII-9) bracketing the weak palaeosol and the basal pedocomplex (PII-10), originally correlated with the 'Göttweiger Verlehmungszone' (GöTzINGER, 1936), was sampled at a depth of $7.8 \mathrm{~m}$ (sample 1401).

\subsection{Göttweig}

Two different sections were investigated near the monastery of Göttweig, just north of the loess sequence at Paudorf (Fig. 4). Section I (Fig. 4a) is the classical site of the 'Göttweiger Verlehmungszone' sensu BAYER (1927) and GöTZINGER (1936), located near the town of Furth in a sunken path. The pedocomplex 'Göttweiger Verlehmung- szone' (unit GI-4) and the overlying up to $6 \mathrm{~m}$ thick loess is exposed horizontally over several hundred meter and lies on a Danube terrace; the correlation with other terraces is unclear. A continuous thin layer (unit GI-2) can be identified in the loess package; preliminary magnetic analysis suggest that this layer is a tephra (pers. comm. U. HAM$\mathrm{BACH}$ ), whose origin and age is unfortunately unclear.

The luminescence sampling points at Section I are shown in Figure 4a. Sample 1406 comes from silty loess (unit GI-1) $0.6 \mathrm{~m}$ above the tephra (unit GI-2), and sample 1405 was taken in sandy-silty yellowish-brown loess (unit GI-3) $0.3 \mathrm{~m}$ below the tephra. Another sample (1407; not shown in Fig. 4) was taken $300 \mathrm{~m}$ upslope $30 \mathrm{~cm}$ below reworked loess which includes pebbles and sandy layers; the position of this sample with respect to the other samples is not unambiguously established but the sampling point definitely lies above the tephra layer.

Section II is located in the hollow way near the village of Aigen (between Göttweig and Paudorf), where a pedocomplex correlated with the 'Paudorfer Bodenbildung' is exposed (FInK, 1976; Fig. 4b). However the pedocomplex (unit GII-3) is eroded at this site, deduced from the lack of an A horizon and a package of $30 \mathrm{~cm}$ thick reworked soil sediment (unit GII-2) covering the soil. The fine-silty yellowish-brown loess (unit GII-1) was sampled $0.7 \mathrm{~m}$ below top ground surface and $0.6 \mathrm{~m}$ above the 'Paudorfer Bodenbildung' (sample 1408); due to induration the sample had 

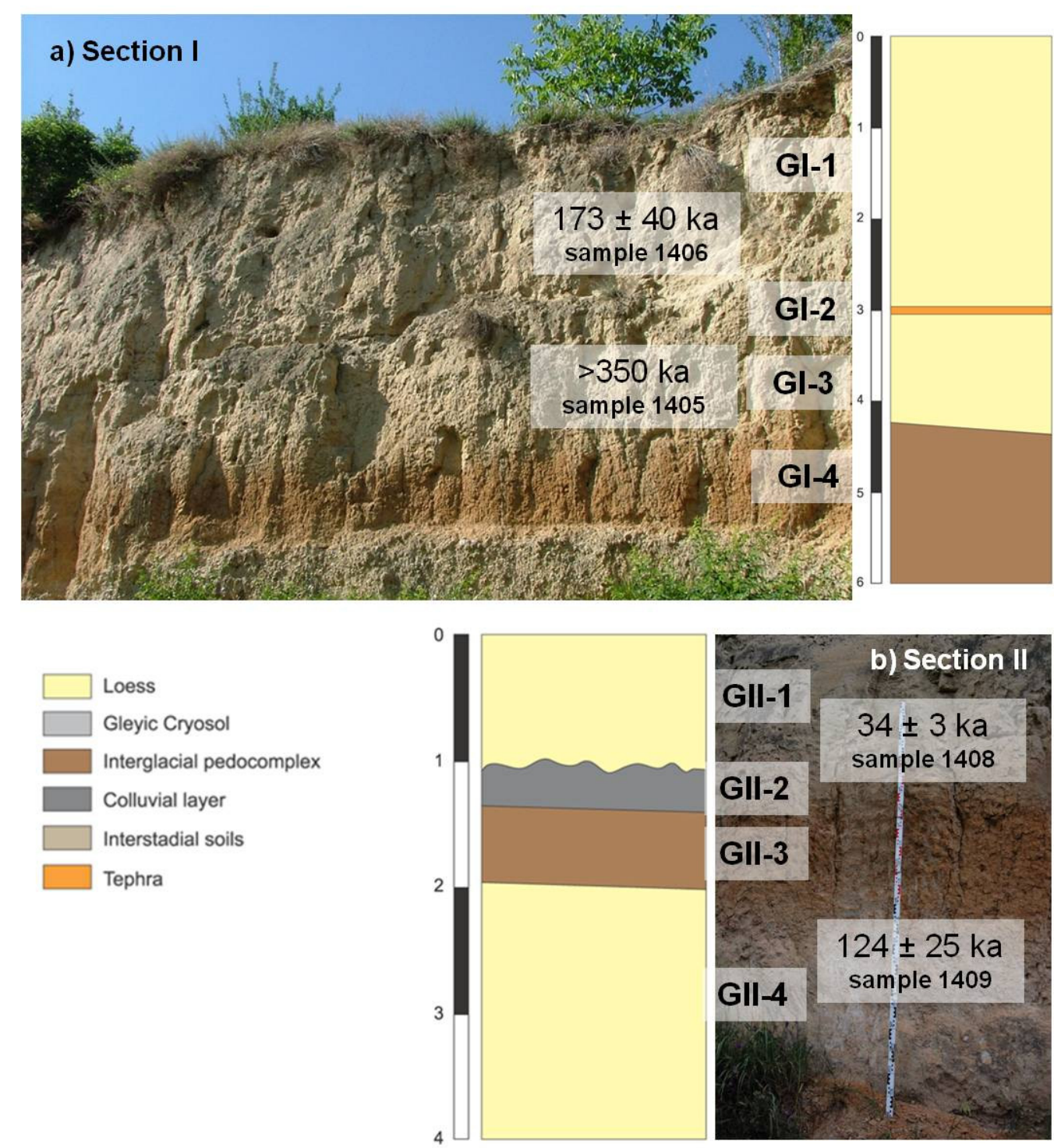

Fig. 4: Photographs and simplified sketches of the loess/palaeosol sequences at Göttweig. a) Section I: type locality of the 'Göttweiger Verlehmungszone' (Göttweig-Furth), b) Section II (Göttweig-Aigen), with 'Paudorfer Bodenbildung' (FINK, 1976). Sample 1407 was taken 300 m upslope from Section I and is not shown in the figure. All ages are derived by post-IR IRSL dating at $290^{\circ} \mathrm{C}$. For details on the material composition, sampling depths and dating see text.

Abb. 4: Fotographie und vereinfachte Profilzeichnungen der Löss-Paläoboden-Sequenzen in der Nähe von Göttweig. a) Aufschluss I: Typlokalität der Göttweiger Verlehmungszone (Göttweig-Furth); b) Aufschluss II (Göttweig-Aigen) mit der Paudorfer Bodenbildung (FINK, 1976). Probe 1407 wurde 300 m hangaufwärts in Göttweig-Furth genommen und ist in der Abbildung nicht zu sehen. Alle Alter wurden mittels post-IR IRSL bei $290^{\circ} \mathrm{C}$ bestimmt. Siehe Text für detaillierte Informationen zu Material, Probentiefe und Datierung.

to be taken as a block. Sample 1409 was taken in carbonate rich silty loess (unit GII-4) $0.6 \mathrm{~m}$ below the 'Paudorfer Bodenbildung' (i.e. $2.5 \mathrm{~m}$ below top ground surface).

\section{Sample preparation and analytical facilities}

In the laboratory, all samples for equivalent dose $\left(D_{e}\right)$ determination were treated under subdued red light. The outer ends $(\sim 1 \mathrm{~cm})$ of the samples might have been exposed to daylight during sampling; these were discarded and the remaining sample treated with hydrochloric acid, sodium oxalate, and hydrogen peroxide. Between each treatment step the sediment was washed with distilled water. Special attention was paid to samples 1402 and 1408 (taken as blocks); all surfaces were scraped off to a depth of $>1 \mathrm{~cm}$ before chemical treatment. The fine-silt fraction $(4-11 \mu \mathrm{m})$ of the samples was extracted by repeated settling and washing (FrECHEN et al., 1996). The polymineral fine-grains were then deposited on aluminium discs (diameter $9.7 \mathrm{~mm}$ ) from a suspension in acetone $(2 \mathrm{mg} / \mathrm{ml})$. Luminescence measurements were made with automated Risø TL/OSL readers (DA-15 and DA-20, respectively; BøTTER-JENSEN et al., 2003; THOMSEN et al., 2006) fitted with calibrated ${ }^{90} \mathrm{Sr} /{ }^{90} \mathrm{Y}$ beta sources calibrated using fine-grained quartz on aluminium discs. The feldspar signal of the polymineral samples was stimulated with infrared light diodes emitting at $870 \mathrm{~nm}$, and the luminescence was detected in the blue-violet region (325-450 nm) through a Schott BG39/Corning 7-59 filter combination.

\section{Dosimetry}

The concentrations of $\mathrm{U}$, Th and $\mathrm{K}$ were determined by high-resolution gamma-ray spectrometry equipped with a high-purity germanium detector. $700 \mathrm{~g}$ of each sample of 
Tab. 1: Summary of dosimetry data. A water content of $15 \pm 5 \%$ was estimated for all samples.

Tab.1: Zusammenfassung der Dosimetriedaten. Ein Wassergehalt von $15 \pm 5 \%$ wurde für alle Proben angenommen.

\begin{tabular}{|l|l|l|l|l|l|}
\hline Sample & K [\%] & $\mathbf{U}[\mathbf{p p m}]$ & Th [ppm] & Cosmic dose rate [Gy/ka] & Total dose rate [Gy/ka] \\
\hline 1398 & $1.2 \pm 0.1$ & $3.0 \pm 0.1$ & $10.6 \pm 0.3$ & $0.18 \pm 0.02$ & $3.1 \pm 0.1$ \\
\hline 1399 & $1.7 \pm 0.1$ & $3.2 \pm 0.1$ & $11.5 \pm 0.4$ & $0.14 \pm 0.02$ & $3.5 \pm 0.2$ \\
\hline 1400 & $0.8 \pm 0.1$ & $2.3 \pm 0.1$ & $7.3 \pm 0.3$ & $0.08 \pm 0.01$ & $2.1 \pm 0.1$ \\
\hline 1401 & $2.2 \pm 0.1$ & $2.8 \pm 0.2$ & $11.4 \pm 0.4$ & $0.13 \pm 0.01$ & $3.8 \pm 0.2$ \\
\hline 1402 & $1.4 \pm 0.1$ & $2.5 \pm 0.1$ & $9.4 \pm 0.3$ & $0.15 \pm 0.02$ & $2.9 \pm 0.1$ \\
\hline 1403 & $1.5 \pm 0.1$ & $2.5 \pm 0.1$ & $9.9 \pm 0.3$ & $0.17 \pm 0.02$ & $3.0 \pm 0.1$ \\
\hline 1404 & $1.6 \pm 0.1$ & $2.8 \pm 0.1$ & $10.9 \pm 0.4$ & $0.20 \pm 0.02$ & $3.3 \pm 0.1$ \\
\hline 1405 & $1.6 \pm 0.1$ & $2.9 \pm 0.1$ & $11.0 \pm 0.4$ & $0.09 \pm 0.01$ & $3.2 \pm 0.2$ \\
\hline 1406 & $1.4 \pm 0.1$ & $2.8 \pm 0.1$ & $9.8 \pm 0.3$ & $0.10 \pm 0.01$ & $2.9 \pm 0.1$ \\
\hline 1407 & $1.5 \pm 0.1$ & $2.9 \pm 0.1$ & $12.9 \pm 0.3$ & $0.11 \pm 0.01$ & $3.4 \pm 0.2$ \\
\hline 1408 & $1.3 \pm 0.1$ & $2.9 \pm 0.1$ & $10.1 \pm 0.3$ & $0.20 \pm 0.02$ & $3.0 \pm 0.3$ \\
\hline 1409 & $0.9 \pm 0.2$ & $2.2 \pm 0.1$ & $6.9 \pm 0.2$ & $0.16 \pm 0.02$ & $2.1 \pm 0.1$ \\
\hline
\end{tabular}

dried material was homogenised and packed in Marinelli beakers, sealed and stored for at least one month to ensure equilibrium between radon and its daughter nuclides before counting. Details about the procedures for dosimetry measurements at the Leibniz Institute for Applied Geophysics (LIAG) laboratory in Hannover are given by KunZ et al. (2010).

The dose rates were derived using the conversion factors of ADAmiEc \& AitKen (1998). For all samples a water content of $15 \pm 5 \%$ was used (FRECHEN et al., 1997) to allow for possible changes in water content throughout time, and a mean a-value of $0.08 \pm 0.02$ was assumed (REES-Jones, 1995). Calculation of the cosmic dose rate is based on Prescotт \& HutTon (1994)

The dosimetry data are summarised in Table 1 . The total dose rates range from $2.1 \pm 0.1 \mathrm{~Gy} / \mathrm{ka}$ to $3.8 \pm 0.2 \mathrm{~Gy} / \mathrm{ka}$. The rather low dose rate of $2.1 \pm 0.1 \mathrm{~Gy} / \mathrm{ka}$ for samples 1400 and 1409 originate in the relatively low Th $(\sim 7 \mathrm{ppm})$ and $\mathrm{K}(<1 \%)$ contents. Nevertheless, all dose rates are within the range expected for European loess (ZÖLLER et al., 1994; FrECHEN et al., 1997; Novothny et al., 2002, 2009; Thiel et al., 2011a, 2011b).

\section{Post-IR IRSL dating}

Since Thomsen et al. (2008) first identified reduced laboratory fading rates from various feldspar signals, several studies have tested or made use of elevated temperature post-IR IRSL signals (e.g. BUYlAERT et al., 2009; ThIEL et al., 2010, 2011a, b; Reimann et al., 2011).

Buylaert et al. (2009) used a preheat of $250^{\circ} \mathrm{C}$ for $60 \mathrm{~s}$ (used in many studies in the past), and their post-IR IR stimulation temperature was chosen to be $225^{\circ} \mathrm{C}$. Because MuRRAY et al. (2009) showed for sand-sized grains of potassium feldspar that there is no systematic increase in equivalent dose measured at $50^{\circ} \mathrm{C}$ for preheat temperatures ranging from $80^{\circ} \mathrm{C}$ up to $320^{\circ} \mathrm{C}$ (60 s duration), Thiel et al. (2011a) adopted a more stringent preheat of $320^{\circ} \mathrm{C}$ for $60 \mathrm{~s}$ to date their polymineral fine-grains with a post-IR IRSL protocol. This allowed them to use post-IR IR stimulation at signifi- cantly higher temperatures. They chose to investigate the use of stimulation at $290^{\circ} \mathrm{C}$ and observed the natural signal of a polymineral fine grain extract from below the Brunhes/Matuyama boundary ( 780 ka, i.e. $\sim 2700 \mathrm{~Gy})$ in saturation on a laboratory growth curve. Based on these observations, they concluded that there is no detectable anomalous fading in nature of the post-IR IRSL signal at $290^{\circ} \mathrm{C}$, even though they were able to measure a finite laboratory fading rate of $\sim 1^{-}$ $1.5 \% /$ decade. THIEL et al. (submitted) have since compared ages obtained using the same post-IR IRSL at $290^{\circ} \mathrm{C}$ protocol with independent age control based on both fission track and radiocarbon dating as well as quartz OSL at two loess sites in Japan (WATANUKI et al., 2005) and obtained very consistent results back to $\sim 600 \mathrm{ka}$. Again they observed a low fading rate in the laboratory $(1.1 \pm 0.2 \%$ /decade; $n=15)$ but argued that no fading correction was necessary.

In the following sections we compare the results obtained using the post-IR IRSL protocol described by BUYLAERT et al. (2009) (post-IR IRSL at $225^{\circ} \mathrm{C}$ ) with those of THIEL et al. (2011a) (post-IR IRSL at $290^{\circ} \mathrm{C}$ ) (Table 2). For comparison the results of the IRSL signal at $50^{\circ} \mathrm{C}$ (measured as part of the post-IR IRSL at $225^{\circ} \mathrm{C}$ protocol) are also discussed.

\subsection{Post-IR IRSL measurements at $225^{\circ} \mathrm{C}$}

For these post-IR IRSL measurements we used the same temperature and stimulation conditions as BUYLAERT et al. (2009). After a preheat of $250^{\circ} \mathrm{C}$ for $60 \mathrm{~s}$, we bleached the polymineral fine-grains (six aliquots per sample) with IR diodes at $50^{\circ} \mathrm{C}$ for $100 \mathrm{~s}$ to recombine the near-neighbour trap/centre pairs which fade most rapidly (discussed in e.g. Poolton et al., 2002; Thomsen et., 2008, 2011), and then held the aliquot at $225^{\circ} \mathrm{C}$ while measuring the IRSL for 100 s. The response to a test dose ( $70 \mathrm{~Gy}$ ) was measured in the same manner (Table 2), and an IR illumination at $290^{\circ} \mathrm{C}$ for $40 \mathrm{~s}$ was inserted at the end of each SAR measurement cycle to reduce the effect of any recuperation (based on MURRAY \& WintLe, 2003). The initial $2.4 \mathrm{~s}$ of the decay curve were used for $\mathrm{D}_{\mathrm{e}}$ determination after subtracting a background from the last $60 \mathrm{~s}$. 

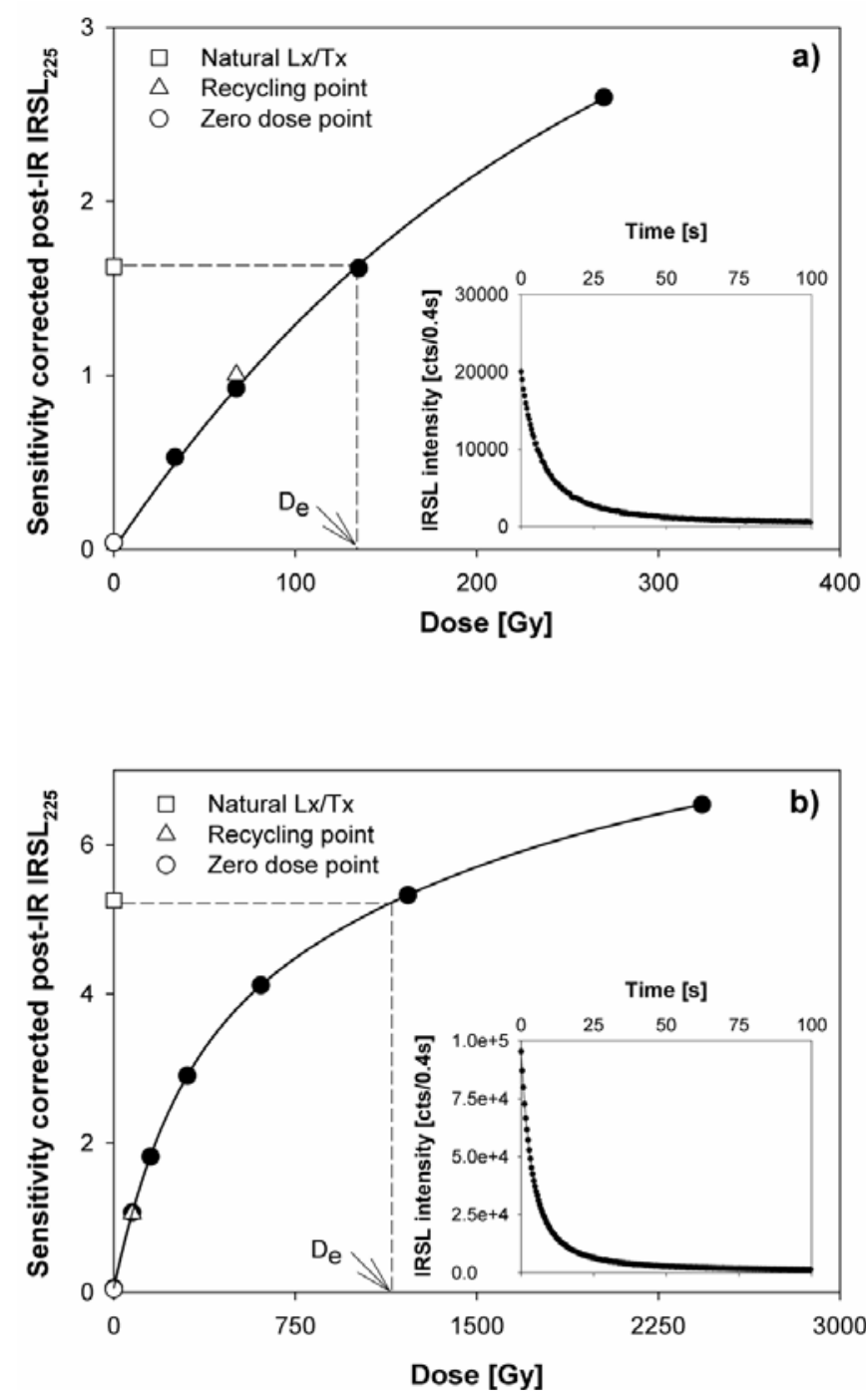

Fig. 5: Dose response and natural decay curves for the post-IR IRSL measurements at $225^{\circ} \mathrm{C}$. a) Dose response curve for sample 1399, representative of younger samples. The inset shows the post-IR IRSL intensity against time (100 s). b) Dose response curve for sample 1407, representative of older samples. The natural sensitivity corrected post-IR IRSL signal (Lx/Tx) is beyond the linear part of the curve. The inset shows the post-IR IRSL intensity against time (100 s).

Abb. 5: Wachstumskurven und natürliche Ausleuchtkurven für die post-IR IRSL-Messungen bei $225^{\circ}$ C. a) Wachstumskurve für Probe 1399 (repräsentiert junges Material). Die eingesetzte Abbildung zeigt die post-IR IRSL-Intensität gegen die Zeit (100 s). b) Wachstumskurve für Probe 1407 (repräsentiert altes Material). Das natürliche, sensitivitätskorrigierte post-IR IRSL-Signal $(L x / T x)$ ist jenseits des linearen Bereiches. Die eingesetzte Abbildung zeigt die post-IR IRSL-Intensität gegen die Zeit (100 s).

The laboratory fading rate was measured on three aliquots per sample as the IRSL signal decreased over time using artificially irradiated aliquots; this is expressed in terms of the percentage decrease of signal intensity per decade of time (the g-value; Aitken, 1985, Appendix F). After a final IR illumination at $290^{\circ} \mathrm{C}$ for $40 \mathrm{~s}$, the same aliquots as for equivalent dose measurements were given doses of $\sim 50$ Gy ('young samples') and 200 Gy ('old samples'), respectively, to monitor anomalous fading using the SAR protocol outlined in Table 2. The storage times after irradiation and preheating (AucLAIR et al., 2003) varied from as brief as experimentally possible ('prompt') to delays of up to $\sim 10$ hours. The $g$-values, calculated using Equation 4 of HuNTLEY $\mho$ LAMOTHE (2001), were normalised to a measurement time delay of 2 days after irradiation.

The dose response curves and the post-IR IRSL decay curves of samples 1399 (a 'young' sample) and 1407 (an 'old' sample) are shown in Figure 5; they are representative of all the other samples presented in this study. The sensitivity-corrected natural of the post-IR IRSL signal of sample 1399 lies on the relatively linear part of the dose response curve, whereas the natural post-IR IRSL signal of sample 1407 (Fig. 5b) clearly lies beyond the linear region, which thus reduces the accuracy of the Huntley \& LAmothe (2001) fading correction.

The ability of a measurement protocol to reproducibly measure the response to a laboratory dose given after repeated heating of the sample is represented by the recycling ratio, which ought to yield values indistinguishable from unity. The recycling ratios for the samples vary between $0.99 \pm 0.01(\mathrm{n}=6$; sample 1407) and $1.05 \pm 0.02(\mathrm{n}=5$; sample 1399) (Table 3 and Fig. 6a). Recuperation is well below $5 \%$ of the natural signal for all except the uppermost sample of the Joching profile (sample 1398), which shows a recuperation of $8.8 \pm 0.5 \%$ ( $n=6)$ (Fig. $6 \mathrm{~b}$ ).

Satisfactory recycling ratios do not necessarily mean that doses given before any heating can also be measured accurately (which is the closest we can come to reproducing natural conditions). We therefore carried out a dose recovery test. Three natural aliquots of samples 1399 (Joching), 1401 (Paudorf) and 1405 (Göttweig) were bleached for 4 hours in a Hönle SOL2 simulator (sample to lamp distance $\sim 1.2 \mathrm{~m}$ to avoid heating of the aliquots). The aliquots were then given a beta dose similar to the measured $\mathrm{D}_{\mathrm{e}}$ for each sample and the given dose was measured in the usual manner. The results of the dose recovery test are shown in Fig. 7a. For all samples, measured/given doses are within $10 \%$ of unity. Because of the residual signals (and hence doses) observed for the postIR IRSL signal at $225^{\circ} \mathrm{C}$ in other studies (THOMSEN et al. 2008; BUYLAERT et al., 2009) we measured the residual signal after bleaching on separate aliquots of the same samples (three per sample). These residual signals were equivalent to a dose of $4.7 \pm 0.5 \mathrm{~Gy}(\mathrm{n}=9)$. After subtraction of these residual doses the measured/given dose ratios vary between $0.97 \pm 0.01$ $(\mathrm{n}=3$; sample 1404) and $1.02 \pm 0.04(\mathrm{n}=3$; sample 1399). Both the measured to given ratios before and after residual subtraction are very close to unity (Fig. 7), demonstrating the accuracy of the measurement protocol when measuring an artificial beta dose given prior to any heating.

\subsection{Post-IR IRSL measurements at $290^{\circ} \mathrm{C}$}

Following Thiel et al. (2011a), after preheating the samples (six aliquots per sample) at $320^{\circ} \mathrm{C}$ for $60 \mathrm{~s}$ we bleached the polymineral fine-grains with IR diodes at $50^{\circ} \mathrm{C}$ for $200 \mathrm{~s}$ and subsequently measured the IRSL at $290^{\circ} \mathrm{C}$ for $200 \mathrm{~s}$. The response to a test dose was measured in the same manner, and an IR illumination at $325^{\circ} \mathrm{C}$ for $100 \mathrm{~s}$ was inserted at the end of each SAR measurement (Table 2). The light sum of the initial $2.4 \mathrm{~s}$ of the post-IR IRSL signal was used for $\mathrm{D}_{\mathrm{e}}$ determination, less a background derived from the last $100 \mathrm{~s}$. The fading rates on three aliquots per sample were measured in exactly the same way as for the IR at $225^{\circ} \mathrm{C}$ signal but using the preheating and stimulation conditions of the post-IR IRSL at $290^{\circ} \mathrm{C}$ protocol. 

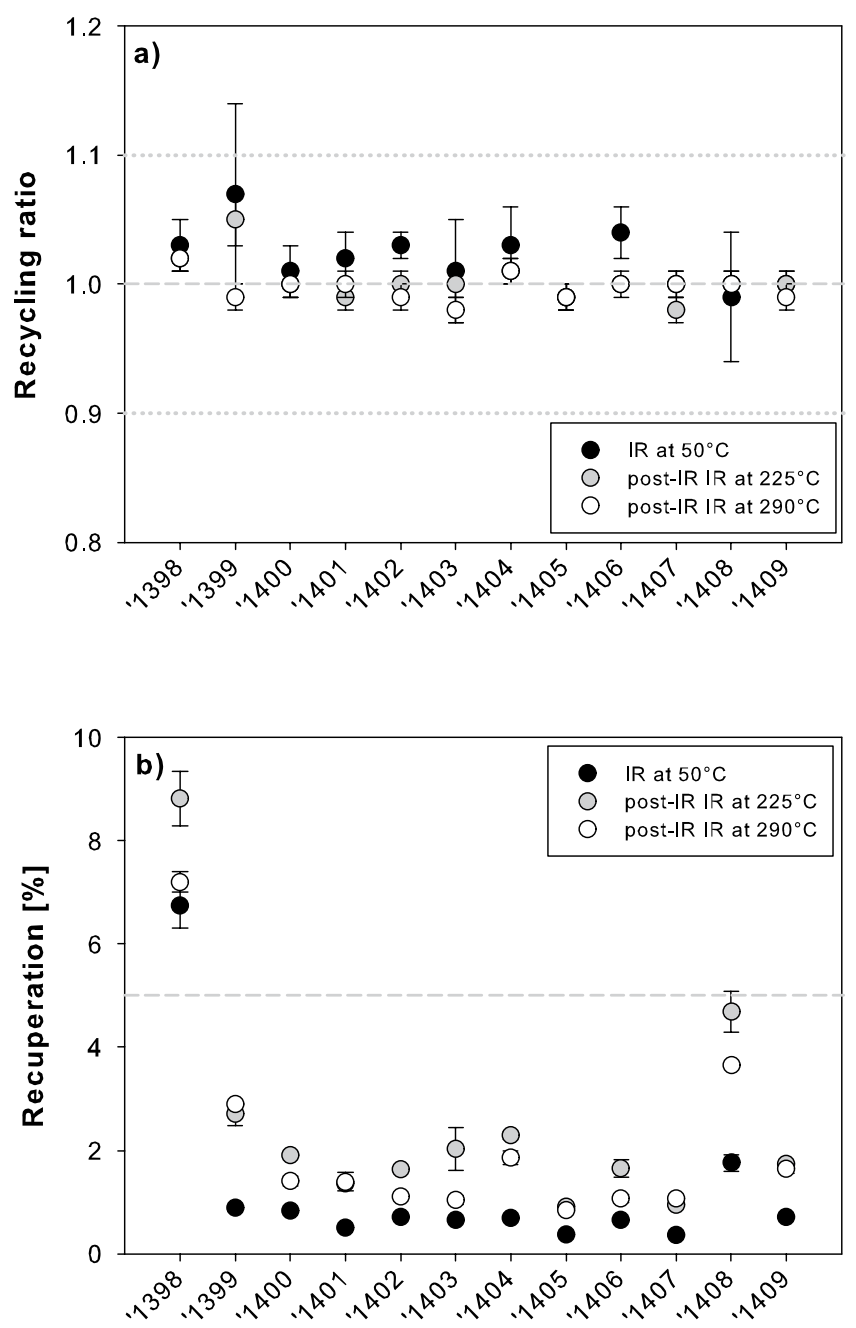

Fig. 6: Recycling ratios and recuperation. a) For all signals and samples the recycling ratios are within 10\% of unity. b) Recuperation [\% of natural signal] for all signals and samples. Sample 1398 shows recuperation $>5 \%$ for all (post-IR) IRSL signals, whereas for all other samples it is well below $5 \%$; for IRSL at $50^{\circ} \mathrm{C}$ it is below $2 \%$.

Abb. 6: Recycling Ratios und Recuperation. a) Die Recycling Ratios sind für alle Signale und Proben im Rahmen der zulässigen 10\%-Abweichung. b) Recuperation [\% des natürlichen Signals] für alle Signale und Proben. Probe 1398 zeigt einen Wert >5\% für alle (post-IR)-IRSL-Signale, während für alle anderen Proben der Wert $<5 \%$ ist. Für IRSL bei $50^{\circ} \mathrm{C}$ liegen die Werte unter $2 \%$.

The dose response curves and the post-IR IRSL signals at $290^{\circ} \mathrm{C}$ of two samples (1399 and 1407) are shown in Figure 8. Whereas the natural post-IR IRSL signal of sample 1399 lies in the linear region of the dose response curve, the natural post-IR IRSL signal of sample 1407 is well above and is approaching saturation. Recycling ratios are very close to unity for all samples (Table 3 and Fig. 6a), and recuperation varies between $0.91 \pm 0.06 \%$ ( $n=6$; sample 1405$)$ and $7.2 \pm 0.2 \%$ ( $\mathrm{n}=6$; sample 1398) (Fig. 8b); except for sample 1398 recuperation is well below $5 \%$ of the natural (the acceptance threshold for quartz OSL suggested by MurRay \& WintLe, 2003). Bleaching for dose recovery tests and residual determination was conducted in the same manner as for the post-IR IRSL measurements at $225^{\circ} \mathrm{C}$. After giving a beta dose close to the natural the dose was measured using the settings described above. Without subtraction of the residual signals (13 \pm 2 Gy; $n=9)$, measured to given dose ratios vary between $1.04 \pm 0.02(n=3$; sample 1404) and $1.08 \pm 0.02(n=3$; sample 1399; Fig. 7a); after subtraction of the residual signals the ratios are $0.99 \pm 0.02(\mathrm{n}=3$; sample 1404) and $1.00 \pm$ 0.01 ( $n=3$; sample 1407; Fig. 7b).

\subsection{IRSL measurements at $50^{\circ} \mathrm{C}$}

The luminescence characteristics and SAR performance for IRSL at $50^{\circ} \mathrm{C}$ presented here are part of the post-IR IRSL measurements at $225^{\circ} \mathrm{C}$. Thus, the data originate from the same aliquots measured in the post-IR IRSL protocol but the decay curves of the IRSL at $50^{\circ} \mathrm{C}$ stimulations are used for all calculations (Table 2). For $\mathrm{D}_{\mathrm{e}}$ determination the initial $2.4 \mathrm{~s}$ of the decay curve were used after subtracting a background from the last $60 \mathrm{~s}$.

The dose response curves for samples 1399 and 1407 are shown in Figure 9. Recycling ratios for all samples are all within $10 \%$ of unity (Table 3 and Fig. 6a), and recuperation varies between $0.4 \pm 0.02 \%$ ( $n=6$; sample 1407$)$ and $6.7 \pm 0.4 \%$ $(\mathrm{n}=6$; sample 1398). The high recuperated signal of sample 1398 is unusual compared to the other values, which are all below $2 \%$ (Fig. 6b).

The residual signals are equivalent to $1.5 \pm 0.2 \mathrm{~Gy}(\mathrm{n}=9)$. Without subtraction of the residual signals the measured to given dose ratios vary between $1.09 \pm 0.02(n=3$; sample $1399)$ and $1.11 \pm 0.04(n=3$; sample 1409; Fig. 7a), whereas after subtraction the ratios lie between $1.08 \pm 0.02 \quad(n=3$; sample 1399) and $1.10 \pm 0.04(\mathrm{n}=3$; sample 1409; Fig. $7 \mathrm{~b})$. Although the results are within $10 \%$ of unity there does seem to be a systematic tendency to overestimate the given dose. Nevertheless, we consider these results acceptable, because they are within the $10 \%$ range.

\section{Comparison of the fading rates and ages derived from the different signals}

The laboratory fading rates for all samples and signals are listed in Table 3 and plotted in Fig. 10. The mean fading rate for IRSL at $50^{\circ} \mathrm{C}$ is $3.3 \pm 0.4 \% /$ decade (excluding the two outliers 1398 and 1400), $2.1 \pm 0.3 \%$ /decade for post-IR IRSL at $225^{\circ} \mathrm{C}$, and $1.0 \pm 0.4 \% /$ decade for post-IR IRSL at $290^{\circ} \mathrm{C}$, confirming that post-IR IR stimulation at higher temperatures reduces fading (THOMSEN et al., 2008).

The fading rates for the IRSL measurements at $50^{\circ} \mathrm{C}$ vary between $1.0 \pm 0.7 \% /$ decade (sample 1401) and $9.9 \pm 0.5 \% /$ decade (sample 1400) and are much higher than for the post-IR IRSL measurements, with the exception of sample 1401; the latter has a fading rate comparable to those of the post-IR IRSL signals (Fig. 10). If this sample indeed does not fade significantly, then the various (uncorrected) $D_{e}$ values should be similar, and ages should be indistinguishable. This, however, is not observed; the $D_{e}$ values for the post-IR IRSL signals are significantly higher than for the IRSL measurement at $50^{\circ} \mathrm{C}$ and as a result the ages do not agree (Table 3 and Fig. 11). Unexpectedly, for sample 1405 the laboratory fading rate of the IRSL signal at $50^{\circ} \mathrm{C}$ is slightly lower $(3.4 \pm 0.3 \% / \mathrm{dec}-$ ade) than that of the post-IR IRSL signal at $225^{\circ} \mathrm{C}(4.3 \pm 0.5 \%$ / decade); the post-IR IRSL at $290^{\circ} \mathrm{C}$ fading rate is much lower $(0.8 \pm 0.4 \% /$ decade $)$ than for both the other signals. Given the fact that our aliquots are made up of many hundreds of thousands of grains, which ought to result in homogeneous luminescence behaviour, the variability observed in the fad- 

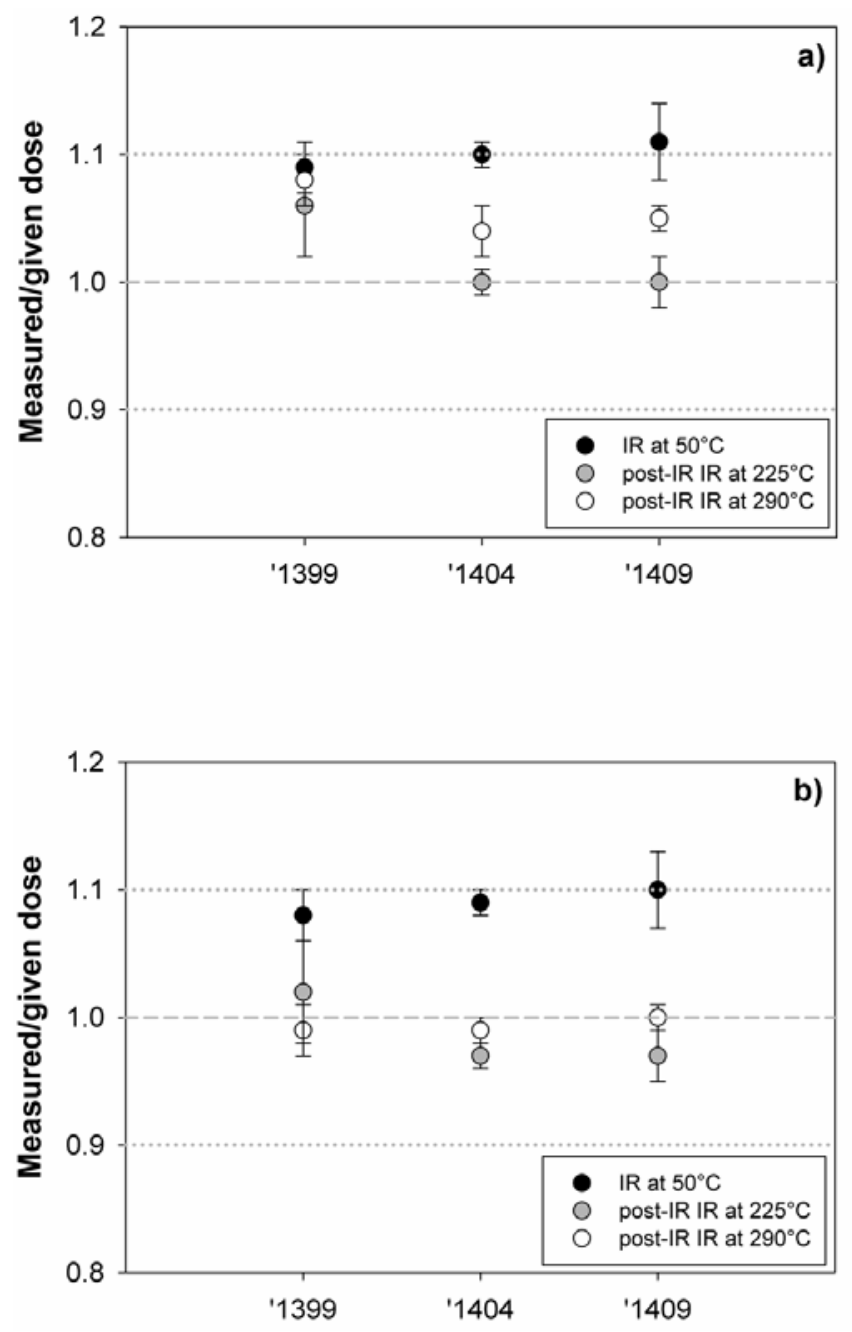

Fig. 7: Results of dose recovery tests a) without residual subtraction, $b$ ) with residual subtraction. The residual signal is $1.5 \pm 0.2 \mathrm{~Gy}(n=9)$ for the IRSL measurements at $50^{\circ} \mathrm{C}, 4.7 \pm 0.5 \mathrm{~Gy}(n=9)$ for the post-IR IRSL measurements at $225^{\circ} \mathrm{C}$, and $13 \pm 2 \mathrm{~Gy}(n=9)$ for the post-IR IRSL measurements at $290^{\circ} \mathrm{C}$. For details about the bleaching conditions and residual measurements see text.

Abb. 7: Ergebnisse der Dose Recovery Tests a) ohne das Restsignal abzuziehen, b) mit Subtraktion des Restsignals. Das Restsignal ist $1.5 \pm 0.2 \mathrm{~Gy}(n=9)$ für die IRSL-Messungen bei $50^{\circ} \mathrm{C}, 4.7 \pm 0.5 \mathrm{~Gy}(n=9)$ für die post-IR IRSL-

Messungen bei $225^{\circ} \mathrm{C}$, und $13 \pm 2 \mathrm{~Gy}(n=9)$ für die post-IR IRSL-Messungen bei $290^{\circ} \mathrm{C}$. Siehe Text für Details zu den Belichtungsexperimenten und Messungen.

ing rates, especially for the IR at $50^{\circ} \mathrm{C}$ signal, is surprising and difficult to explain; although it could originate from e.g. a change in source area, it seems more likely that it reflects some unknown laboratory source of variability.

THIEL et al. (2011a) measured fading rates of $1-1.5 \% /$ decade using the post-IR IRSL signal measured at $290^{\circ} \mathrm{C}$ for their polymineral fine-grain samples; they argued that because the natural signals from these samples were in saturation on a laboratory growth curve, it was unlikely that the natural signal had faded significantly. In addition, they also measured a fading rate of $\sim 1 \% /$ decade for fine-grained quartz dominated by a fast OSL component; it seems clear that at the very least their post-IR IRSL signal did not fade any more than the blue-stimulated OSL signals from quartz. It may be that fading rates below $1 \%$ /decade are not meaningful, and in fact reflect systematic errors in laboratory fading measurements.

We have confirmed that for the higher temperature sig- nals smaller fading rates are obtained and as a consequence it is expected that the fading uncorrected ages of the IRSL signal at $50^{\circ} \mathrm{C}$ ought to be younger than for any post-IR IRSL measurement. If fading measurements and fading corrections are applicable (HUNTLEY \& LAMOTHE, 2001), and if post-IR IRSL at $290^{\circ} \mathrm{C}$ does not show significant anomalous fading as suggested by THIEL et al. (2011a, accepted), fading corrected IRSL ages at $50^{\circ} \mathrm{C}$ and fading corrected post-IR IRSL ages at $225^{\circ} \mathrm{C}$ should be indistinguishable from fading uncorrected ages for the post-IR IRSL at $290^{\circ} \mathrm{C}$, at least over the dose range for which the HuntLEy \& LAMOTHE (2001) correction may be applicable in practice ( 200 Gy; BuylaErT et al., 2011). The fading uncorrected and fading corrected ages are listed in Table 3 and shown in Figure 11. We assume that the post-IR IRSL at $290^{\circ} \mathrm{C}$ gives the most accurate age estimates because there is evidence that these signals do not fade in nature (THIEL et al., 2011a, accepted); this can also be concluded from sample 1405, which is in or close to saturation, since laboratory saturation in feldspar is only possible when fading is negligible.

As expected, the fading uncorrected ages of the IRSL signal at $50^{\circ} \mathrm{C}$ (showing the largest fading rates) underestimates compared to the post-IRSL at $290^{\circ} \mathrm{C}$ (Fig. 11a); the age underestimation is most evident for the older samples. On the other hand, uncorrected post-IR IRSL at $225^{\circ} \mathrm{C}$ ages only slightly underestimate compared to post-IR IRSL at $290^{\circ} \mathrm{C}$ (Fig. 11b). The measured post-IR IRSL at $225^{\circ} \mathrm{C}$ laboratory fading rates (0.6 to $4.3 \% /$ decade; Table 3$)$, at least when $>1 \%$ /decade, are probably significant, and it seems clear that the post-IR IRSL at $225^{\circ} \mathrm{C}$ needs fading correction. A similar observation was made by BuylaERT et al. (2009) for their Eemian samples (see supplementary table in BuYLAERT et al., 2009). The fading corrected ages for post-IR IRSL at $225^{\circ} \mathrm{C}$ are plotted against corrected ages for post-IR IRSL at $290^{\circ} \mathrm{C}$ in Figure 11c, and against uncorrected ages for post-IR IRSL at $290^{\circ} \mathrm{C}$ in Figure $11 \mathrm{~d}$. It is recognised that the correction model is theoretically not applicable at higher doses, but such qualifications become of second order importance when the correction is so small. The fading correction for post-IR IRSL at $290^{\circ} \mathrm{C}$ is, on average, $<10 \%$ of the age and so Figures $11 \mathrm{c}$ and $11 \mathrm{~d}$ are very similar. In both figures the agreement between the ages derived from the two signals is satisfactory with one exception (sample 1403), for which either post-IR IRSL at $225^{\circ} \mathrm{C}$ underestimates, or post-IR IRSL at $290^{\circ} \mathrm{C}$ overestimates.

The agreement between the fading corrected ages for IRSL at $50^{\circ} \mathrm{C}$ with the fading uncorrected (or corrected) ages for post-IR IRSL at $290^{\circ} \mathrm{C}$ is slightly poorer, especially for the older samples (> $100 \mathrm{ka}$; Fig. 11e). Sample 1400 , which has a fading rate of $9.9 \pm 0.5 \%$ /decade resulted in a significantly overestimated age after correction of $679 \pm 74$ ka (Table 3). This sample is well outside the applicable range of the HunTLEY \& LAMOTHE (2001) correction model, but this should result in an underestimation, not overestimation; however, it is most likely that the fading rate for this sample is overestimated. A depositional age of $>600 \mathrm{ka}$ for this sample is unlikely not only from a stratigraphical point of view but also when compared with the post-IR IRSL age estimates. The overestimation is consistent with the observations of REIMANN et al. (2011) using Holocene coastal sediments (to which the correction model is defi- 
Tab. 2: Flowcharts of the post-IR IRSL SAR protocols (BUYLAERT et al., 2009; THIEL et al., 2011a). For IRSL at $50^{\circ} \mathrm{C}$ steps 3 and 7 of protocol a) were used for equivalent dose determination.

Tab. 2: Ablaufschema für die post-IR IRSL SAR-Protokolle (BUYLAERT et al., 2009; THIEL et al., 2011a). Für IRSL bei $50^{\circ} \mathrm{C}$ wurden Schritt 3 und 7 von Protokoll a) für die Äquivalenzdosis-Bestimmung verwendet.

\begin{tabular}{|l|l|l|l|l|l|}
\hline a] & & & b] & & \\
\hline Step & Treatment & Observed & Step & Treatment & Observed \\
\hline 1 & Give dose, $\mathrm{D}_{\mathrm{i}}$ & & 1 & Give dose, $\mathrm{D}_{\mathrm{i}}$ & \\
\hline 2 & Preheat, $250^{\circ} \mathrm{C}, 60 \mathrm{~s}$ & & 2 & Preheat, $320^{\circ} \mathrm{C}, 60 \mathrm{~s}$ & \\
\hline 3 & IR stimulation, $100 \mathrm{~s}$ at $50^{\circ} \mathrm{C}$ & & 3 & IR stimulation, $200 \mathrm{~s}$ at $50^{\circ} \mathrm{C}$ & \\
\hline 4 & IR stimulation, $100 \mathrm{~s}$ at $225^{\circ} \mathrm{C}$ & $\mathrm{L}_{\mathrm{x}}$ & 4 & IR stimulation, $200 \mathrm{~s}$ at $290^{\circ} \mathrm{C}$ & $\mathrm{L}_{\mathrm{x}}$ \\
\hline 5 & Give test dose, $\mathrm{D}_{\mathrm{T}}$ & & 5 & Give test dose, $\mathrm{D}_{\mathrm{T}}$ & \\
\hline 6 & Preheat, $250^{\circ} \mathrm{C}, 60 \mathrm{~s}$ & & 6 & Preheat, 320 ${ }^{\circ} \mathrm{C}, 60 \mathrm{~s}$ & \\
\hline 7 & IR stimulation, $100 \mathrm{~s}$ at $50^{\circ} \mathrm{C}$ & & 7 & IR stimulation, $200 \mathrm{~s}$ at $50^{\circ} \mathrm{C}$ & $\mathrm{T}_{\mathrm{x}}$ \\
\hline 8 & IR stimulation, $100 \mathrm{~s}$ at $225^{\circ} \mathrm{C}$ & $\mathrm{T}_{\mathrm{x}}$ & 8 & IR stimulation, $200 \mathrm{~s}$ at $290^{\circ} \mathrm{C}$ & \\
\hline 9 & IR stimulation, $40 \mathrm{~s}$ at $290^{\circ} \mathrm{C}$ & & 9 & IR stimulation, $100 \mathrm{~s}$ at $325^{\circ} \mathrm{C}$ & \\
\hline 10 & Return to 1 & & 10 & Return to 1 & \\
\hline
\end{tabular}

nitely applicable); they show that fading correction of the IRSL signal at $50^{\circ} \mathrm{C}$ for $g$-values $>6 \% /$ decade overestimates their depositional ages for which independent age control is available.

In most post-IR IRSL dating studies (e.g. BUYLAERT et al., 2009; Thiel et al., 2011a, b; ReimanN et al., 2011) it has been observed that a significant residual post-IR IRSL signal is present after daylight or solar simulator bleaching in the laboratory. ThOMSEN et al. (2008) showed in a bleaching experiment that there is no obvious difference in signal resetting between the IRSL at $50^{\circ} \mathrm{C}$ signal and the post-IR IRSL signal at $225^{\circ} \mathrm{C}$. Nevertheless, using the same postIR IRSL signal, BUyLAERT et al. (2009) found apparent residuals of up to $2 \mathrm{~Gy}$ for modern samples while residuals measured using IR at $50^{\circ} \mathrm{C}$ were $\sim 0.5 \mathrm{~Gy}$; either the two signals bleach to different degrees, or there are differences in thermal transfer. In contrast, THIEL et al. (2011a) measured laboratory residuals equivalent to $15-20 \mathrm{~Gy}$ for the post-IR IRSL signal at $290^{\circ} \mathrm{C}$. For their samples it was difficult to decide on the relevance of these residual measurements to naturally bleached samples because there were no modern analogues available at their site. Again, some or all of the residual doses may have arisen through thermal transfer following the higher preheat temperature of $320^{\circ} \mathrm{C}$. Thus it remains unclear to what degree the post-IR IRSL signals bleach more slowly than the IR at $50^{\circ} \mathrm{C}$ for these samples, or whether the differences are a result of the different preheat temperatures used (i.e. thermal transfer).

None of the ages presented here have had a residual dose subtracted. From laboratory bleaching experiments, apparent residuals can vary between $1.5 \pm 0.2 \mathrm{~Gy}(\mathrm{n}=9)$ for IRSL at $50^{\circ} \mathrm{C}$ and $13 \pm 2 \mathrm{~Gy}(\mathrm{n}=9)$ for post-IR IRSL at $290^{\circ} \mathrm{C}$. In nature bleaching is likely to be episodic and take place over much longer times than is typical for laboratory bleaching experiments. One can test the size of any residual by determining the luminescence age on material of independently known young age, or by examining the dose in recently transported modern material (modern analogues). Unfortunately, there are no modern analogues available at our sites. To test the bleachability of the different IRSL signals the ages of the younger ( $<70 \mathrm{ka})$ samples are compared (Fig. 11f). The IRSL at $50^{\circ} \mathrm{C}$ ages are taken as reference because there is good evidence in the literature that the signal can be bleached to very low levels (e.g. Huntley \& Clague, 1996) and in this age range the fading correction is generally expected to yield accurate results (HuntLey \& LAMOTHE, 2001; Buylaert et al., 2011). For the youngest sample (sample 1398 ; IRSL at $50^{\circ} \mathrm{C}$ $\mathrm{D}_{\mathrm{e}}: 15 \pm 2 \mathrm{~Gy}$ ), which might be expected to be significantly affected by residual doses, the post-IR IRSL ages are slightly older than the corrected IRSL age at $50^{\circ} \mathrm{C}$. However, for this sample the corrected IRSL age at $50^{\circ} \mathrm{C}$ of $10 \pm 1$ ka seems, from a geological point of view too young, since there was no loess deposition in Lower Austria during the Holocene. The post-IR IRSL ages are thus closer to the expected age. This gives confidence that the post-IR IRSL signals are bleachable in nature, and as a result we do not subtract any residual from any of our ages. Nevertheless this assumption needs further testing using modern analogues and/or very young samples.

In summary, for young samples, for which the fading correction of the $225^{\circ} \mathrm{C}$ signal is likely to be accurate, both the fading corrected ages for post-IR IRSL at $225^{\circ} \mathrm{C}$ and the fading uncorrected ages for post-IR IRSL at $290^{\circ} \mathrm{C}$ seem to yield comparable results. For older samples any fading correction is likely to be increasingly inaccurate, and we favour the age estimates from the post-IR IRSL at $290^{\circ} \mathrm{C}$, which apparently do not require significant fading correction (THIEL et al., 2011a, accepted). The following discussion on the chronological framework of the palaeosols is hence based on this IRSL signal unless otherwise stated.

\section{Chronostratigraphy of the palaeosols}

In Joching the loess unit J1 above the Cryosol complex (sample 1398) was dated to $16 \pm 2 \mathrm{ka}$, whereas the 'Bröckelsand' (sample 1399) was dated to $47 \pm 3 \mathrm{ka}$. This allows for formation of the Cryosol complex sometime between $\sim 45 \mathrm{ka}$ and $\sim 20 \mathrm{ka}$. Cryosols in Lower Austria were described at Stratzing and luminescence dated to $\sim 27-33 \mathrm{ka}$ (THIEL et al., 2011a). This is in agreement with HAEsEARTs et al. (1996), who have 

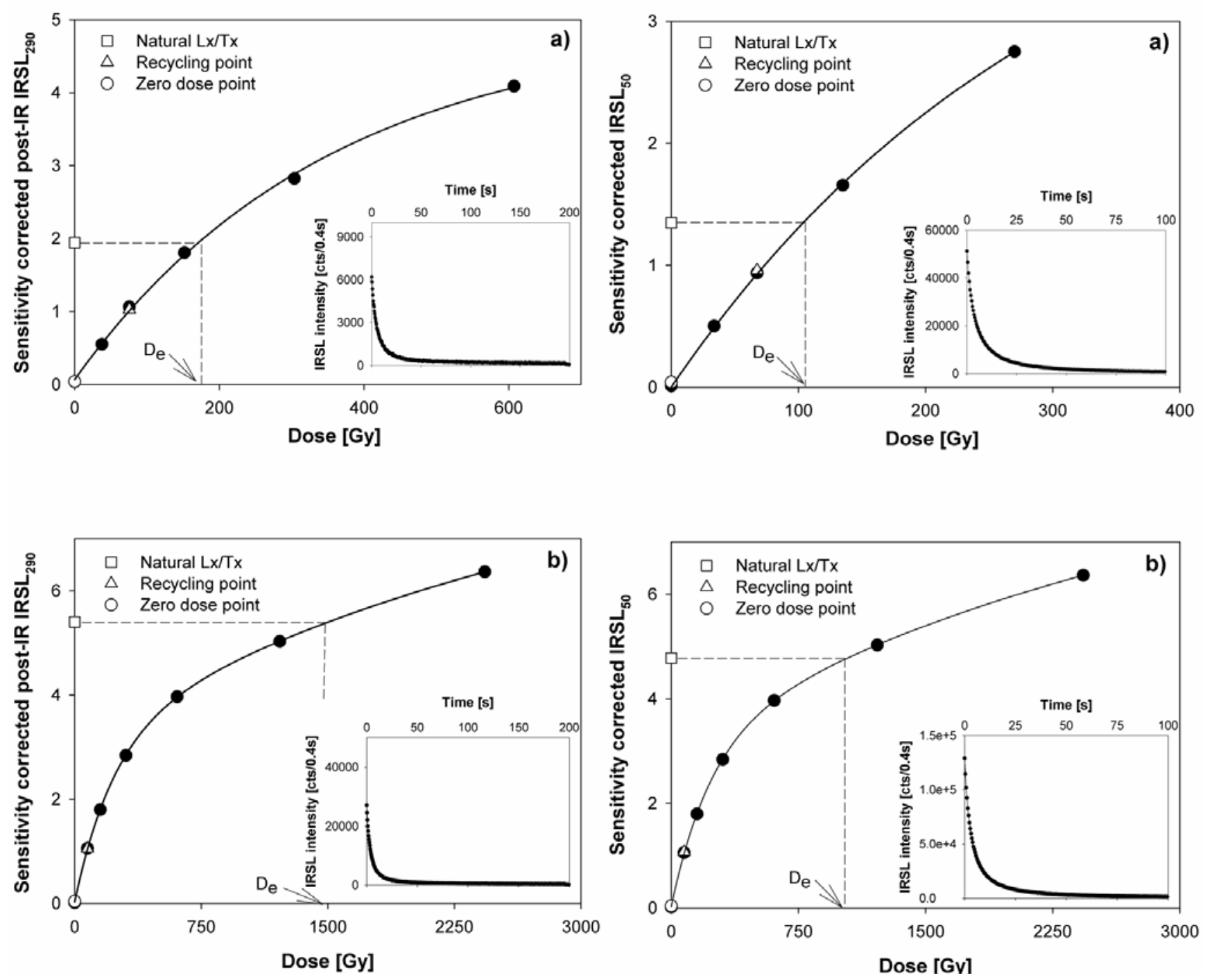

Fig. 8: Dose response and natural decay curves for the post-IR IRSL measurements at $290^{\circ} \mathrm{C}$. a) Dose response curve for sample 1399, representative of younger samples. The natural Lx/Tx lies in the linear part of the curve. b) Dose response curve for sample 1407, representative of older samples. The natural Lx/Tx approaches saturation. The insets show the IRSL intensity against time (200 s).

Abb. 8: Wachstumskurven und natürliche Ausleuchtkurven für die post-IR IRSL-Messungen bei $290^{\circ} \mathrm{C}$. a) Wachstumskurve für Probe 1399 (repräsentiert junges Material). Das natürliche Signal (Lx/Tx) liegt im linearen Bereich der Kurve. b) Wachstumskurve für Probe 1407 (repräsentiert altes Material). Das natürliche, sensitivitätskorrigierte post-IR IRSL-Signal (Lx/Tx) liegt nahe der Sättigungsgrenze. Die eingesetzten Abbildungen zeigen die postIR IRSL-Intensität gegen die Zeit (200 s).

presented several radiocarbon ages (charcoal) from various sites in Lower Austria pointing to formation of the Cryosols between 27 and $39 \mathrm{ka}$. The loess unit J9 underlying the pedocomplex (sample 1400) was dated to $170 \pm 16 \mathrm{ka}$ (MIS 6); it is therefore likely that the pedocomplex (unit J6-J8) developed during MIS 5; however, an unequivocal attribution to a sub-stage is not possible. Because the pedocomplex is composed of three horizons, it is possible that it comprises the entire MIS 5 with its sub-stages. The pedocomplex in Joching might thus be correlated with the 'Paudorfer Bodenbildung' (unit PI-3; Fig. 3), which at its type locality in Paudorf de-
Fig. 9: Dose response and natural decay curves for the IRSL measurements at $50^{\circ} \mathrm{C}$ as part of the post-IR IRSL measurements at $225^{\circ} \mathrm{C}$, i.e. the same aliquots are used. a) Dose response curve for sample 1399, representative of younger samples. The natural Lx/Tx lies in the linear part of the curve. $b$ ) Dose response curve for sample 1407, representative of older samples. The natural Lx/Tx is beyond the linear part of the curve, nevertheless nowhere near saturation. The insets show the IRSL intensity against time (100 s).

Abb. 9: Wachstumskurven und natürliche Ausleuchtkurven für die IRSLMessungen bei $50^{\circ} \mathrm{C}$ (als Teil der post-IR IRSL-Messungen bei $225^{\circ} \mathrm{C}$, d.h. dieselben Aliquoten wurden verwendet). a) Wachstumskurve für Probe 1399 (repräsentiert junges Material). Das natürliche Signal (Lx/Tx) liegt im linearen Bereich der Kurve. b) Wachstumskurve für Probe 1407 (repräsentiert altes Material). Das natürliche, sensitivitätskorrigierte post-IR IRSL-Signal $(L x / T x)$ liegt oberhalb des linearen Bereiches, jedoch nicht annähernd in Sättigung. Die eingesetzten Abbildungen zeigen die post-IR IRSL-Intensität gegen die Zeit (100 s).

veloped during MIS 5 . This is shown by the age of the loess unit PI-2 above the 'Paudorfer Bodenbildung' of $106 \pm 12$ ka (sample 1404), whereas the loess below (unit PI-4) gives an age of $159 \pm 20 \mathrm{ka}$ (post-IR IRSL at $225^{\circ} \mathrm{C}$; sample 1403). Here, it has to be noted that the age of $299 \pm 33$ ka derived from post-IR IRSL at $290^{\circ} \mathrm{C}$ seems to be an overestimate; this is likely because the ratio of $\mathrm{D}_{\mathrm{e}}$ 's obtained (post-IR IRSL at $290^{\circ} \mathrm{C}$ /post-IR IRSL at $225^{\circ} \mathrm{C}$ ) is for all samples $<1.5$, whereas for sample 1403 it is 2.1 . Hence, for sample 1403, the fading corrected post-IR IRSL at $225^{\circ} \mathrm{C}$ age of $159 \pm 20$ (Table 3 ) seems the most reliable result and is, within errors, in agree- 
Tab. 3: Recycling ratios, equivalent doses $\left(D_{e}\right)$, fading rates, and fading uncorrected and fading corrected ages for the three (post-IR) IRSL signals. For all samples six aliquots were measured for $D_{e}$ determination. The fading uncorrected ages for the post-IR IRSL signal at $290^{\circ} \mathrm{C}$ (in bold) are considered the most reliable (apart from sample 1403 for which the corrected age of post-IR IRSL at $225^{\circ} \mathrm{C}$ is considered the most reliable estimate). For details see text. Tab. 3: Recycling Ratios, Äquivalenzdosen $\left(D_{e}\right)$, Fading-Raten und nicht-korrigierte sowie korrigierte Alter für die drei (post-IR) IRSL-Signale. Für alle Proben wurden sechs Aliquoten für die Bestimmung der Äquivalenzdosis verwendet. Die nicht-korrigierten Alter des post-IR IRSL-Signals bei $290^{\circ} \mathrm{C}$ (in fett) sind die zuverlässigsten (bis auf Probe 1403, für die das korrigierte Alter des post-IR IRSL-Signals bei $225^{\circ} \mathrm{C}$ am zuverlässigsten angesehen wird). Siehe Text für Details.

\begin{tabular}{|c|c|c|c|c|c|c|c|}
\hline Location & Sample & Signal & Recycling ratio & $D_{e}[G y]$ & $\begin{array}{l}\text { Fading rate } \\
\text { [\%/decade] }\end{array}$ & $\begin{array}{l}\text { Fading } \\
\text { uncorrected age } \\
\text { [ka] }\end{array}$ & $\begin{array}{l}\text { Fading } \\
\text { corrected age } \\
\text { [ka] }\end{array}$ \\
\hline \multirow{9}{*}{ Joching } & \multirow{3}{*}{1398} & IRSL at $50^{\circ} \mathrm{C}^{*}$ & $1.03 \pm 0.02$ & $15 \pm 2$ & $8.0 \pm 0.5$ & $5 \pm 1$ & $10 \pm 1$ \\
\hline & & pIR IRSL at $225^{\circ} \mathrm{C}$ & $1.02 \pm 0.01$ & $33 \pm 3$ & $2.8 \pm 0.2$ & $11 \pm 1$ & $13 \pm 1$ \\
\hline & & pIR IRSL at $290^{\circ} \mathrm{C}$ & $1.02 \pm 0.01$ & $50 \pm 5$ & $1.3 \pm 0.5$ & $16 \pm 2$ & $18 \pm 2$ \\
\hline & \multirow{3}{*}{1399} & IRSL at $50^{\circ} \mathrm{C}^{*}$ & $1.07 \pm 0.07$ & $140 \pm 15$ & $4.3 \pm 0.5$ & $40 \pm 4$ & $58 \pm 8$ \\
\hline & & pIR IRSL at $225^{\circ} \mathrm{C}$ & $1.05 \pm 0.02$ & $148 \pm 11$ & $1.8 \pm 0.1$ & $42 \pm 2$ & $49 \pm 4$ \\
\hline & & pIR IRSL at $290^{\circ} \mathrm{C}$ & $0.99 \pm 0.01$ & $163 \pm 10$ & $0.9 \pm 0.5$ & $47 \pm 4$ & $50 \pm 5$ \\
\hline & \multirow{3}{*}{1400} & IRSL at $50^{\circ} \mathrm{C}^{*}$ & $1.01 \pm 0.02$ & $329 \pm 34$ & $9.9 \pm 0.5$ & $157 \pm 17$ & $679 \pm 74$ \\
\hline & & pIR IRSL at $225^{\circ} \mathrm{C}$ & $1.00 \pm 0.01$ & $337 \pm 32$ & $2.7 \pm 0.2$ & $160 \pm 17$ & $201 \pm 19$ \\
\hline & & pIR IRSL at $290^{\circ} \mathrm{C}$ & $1.00 \pm 0.01$ & $356 \pm 32$ & $1.0 \pm 0.3$ & $170 \pm 16$ & $183 \pm 19$ \\
\hline \multirow{12}{*}{ Paudorf } & \multirow{3}{*}{1401} & IRSL at $50^{\circ} \mathrm{C}^{*}$ & $1.02 \pm 0.02$ & $474 \pm 37$ & $1.0 \pm 0.7$ & $125 \pm 10$ & $135 \pm 12$ \\
\hline & & pIR IRSL at $225^{\circ} \mathrm{C}$ & $0.99 \pm 0.01$ & $596 \pm 20$ & $1.2 \pm 0.2$ & $157 \pm 10$ & $172 \pm 15$ \\
\hline & & pIR IRSL at $290^{\circ} \mathrm{C}$ & $1.00 \pm 0.01$ & $714 \pm 58$ & $1.1 \pm 0.2$ & $189 \pm 16$ & $204 \pm 20$ \\
\hline & \multirow{3}{*}{1402} & IRSL at $50^{\circ} \mathrm{C}^{*}$ & $1.03 \pm 0.01$ & $344 \pm 15$ & $2.2 \pm 0.6$ & $119 \pm 6$ & $141 \pm 13$ \\
\hline & & pIR IRSL at $225^{\circ} \mathrm{C}$ & $1.00 \pm 0.01$ & $427 \pm 44$ & $0.6 \pm 0.6$ & $147 \pm 16$ & $154 \pm 20$ \\
\hline & & pIR IRSL at $290^{\circ} \mathrm{C}$ & $0.99 \pm 0.01$ & $538 \pm 34$ & $0.7 \pm 0.5$ & $187 \pm 12$ & $195 \pm 20$ \\
\hline & \multirow{3}{*}{1403} & $\mathrm{IRSL}$ at $50^{\circ} \mathrm{C}^{*}$ & $1.01 \pm 0.04$ & $353 \pm 19$ & $4.3 \pm 0.6$ & $118 \pm 7$ & $172 \pm 19$ \\
\hline & & pIR IRSL at $225^{\circ} \mathrm{C}$ & $1.00 \pm 0.01$ & $414 \pm 44$ & $1.8 \pm 0.1$ & $138 \pm 15$ & $159 \pm 20$ \\
\hline & & pIR IRSL at $290^{\circ} \mathrm{C}$ & $0.98 \pm 0.01$ & $897 \pm 97$ & $0.7 \pm 0.3$ & $299 \pm 33$ & $315 \pm 41$ \\
\hline & \multirow{3}{*}{1404} & $\mathrm{IRSL}$ at $50^{\circ} \mathrm{C}^{*}$ & $1.03 \pm 0.03$ & $234 \pm 20$ & $3.7 \pm 0.6$ & $71 \pm 6$ & $97 \pm 12$ \\
\hline & & pIR IRSL at $225^{\circ} \mathrm{C}$ & $1.01 \pm 0.01$ & $225 \pm 19$ & $1.5 \pm 0.2$ & $68 \pm 6$ & $77 \pm 9$ \\
\hline & & pIR IRSL at $290^{\circ} \mathrm{C}$ & $1.01 \pm 0.01$ & $351 \pm 40$ & $1.5 \pm 0.4$ & $106 \pm 12$ & $120 \pm 16$ \\
\hline \multirow{15}{*}{ Göttweig } & \multirow{3}{*}{1405} & IRSL at $50^{\circ} \mathrm{C}^{*}$ & $0.99 \pm 0.01$ & $728 \pm 51$ & $3.4 \pm 0.3$ & $228 \pm 17$ & $304 \pm 30$ \\
\hline & & pIR IRSL at $225^{\circ} \mathrm{C}$ & $0.99 \pm 0.01$ & $1295 \pm 83$ & $4.3 \pm 0.5$ & $>300$ & $>300$ \\
\hline & & pIR IRSL at $290^{\circ} \mathrm{C}$ & $0.99 \pm 0.01$ & $1845 \pm 483$ & $0.8 \pm 0.4$ & $>350$ & $>350$ \\
\hline & \multirow{3}{*}{1406} & IRSL at $50^{\circ} \mathrm{C}^{*}$ & $1.04 \pm 0.02$ & $440 \pm 47$ & $4.6 \pm 0.6$ & $152 \pm 16$ & $230 \pm 34$ \\
\hline & & pIR IRSL at $225^{\circ} \mathrm{C}$ & $1.00 \pm 0.00$ & $537 \pm 30$ & $2.3 \pm 0.3$ & $185 \pm 12$ & $233 \pm 19$ \\
\hline & & pIR IRSL at $290^{\circ} \mathrm{C}$ & $1.00 \pm 0.01$ & $503 \pm 115$ & $1.2 \pm 0.3$ & $173 \pm 40$ & $190 \pm 46$ \\
\hline & \multirow{3}{*}{1407} & IRSL at $50^{\circ} \mathrm{C}^{*}$ & $1.00 \pm 0.01$ & $847 \pm 125$ & $3.2 \pm 0.3$ & $249 \pm 38$ & $327 \pm 53$ \\
\hline & & pIR IRSL at $225^{\circ} \mathrm{C}$ & $0.98 \pm 0.01$ & $1149 \pm 96$ & $2.9 \pm 0.5$ & >280 & $>280$ \\
\hline & & pIR IRSL at $290^{\circ} \mathrm{C}$ & $1.00 \pm 0.01$ & $1265 \pm 78$ & $0.9 \pm 0.3$ & $>300$ & $>300$ \\
\hline & \multirow{3}{*}{1408} & IRSL at $50^{\circ} \mathrm{C}^{*}$ & $0.99 \pm 0.05$ & $75 \pm 6$ & $3.3 \pm 0.4$ & $25 \pm 2$ & $33 \pm 4$ \\
\hline & & pIR IRSL at $225^{\circ} \mathrm{C}$ & $1.00 \pm 0.01$ & $83 \pm 6$ & $2.0 \pm 0.5$ & $28 \pm 3$ & $32 \pm 4$ \\
\hline & & pIR IRSL at $290^{\circ} \mathrm{C}$ & $1.00 \pm 0.01$ & $101 \pm 8$ & $0.9 \pm 0.4$ & $34 \pm 3$ & $36 \pm 4$ \\
\hline & \multirow{3}{*}{1409} & IRSL at $50^{\circ} \mathrm{C}^{*}$ & $1.00 \pm 0.01$ & $244 \pm 16$ & $3.1 \pm 0.3$ & $116 \pm 8$ & $151 \pm 13$ \\
\hline & & pIR IRSL at $225^{\circ} \mathrm{C}$ & $1.00 \pm 0.01$ & $294 \pm 23$ & $1.3 \pm 0.4$ & $140 \pm 13$ & $155 \pm 15$ \\
\hline & & pIR IRSL at $290^{\circ} \mathrm{C}$ & $0.99 \pm 0.01$ & $263 \pm 53$ & $0.7 \pm 0.3$ & $124 \pm 25$ & $132 \pm 30$ \\
\hline
\end{tabular}

* The equivalent doses of the IRSL signal at $50^{\circ} \mathrm{C}$ are derived from the same measurement cycle as the post-IR IRSL $\left(225^{\circ} \mathrm{C}\right)$ results, i.e. preheat of $250^{\circ} \mathrm{C}$. The same applies to the measured fading rates. 


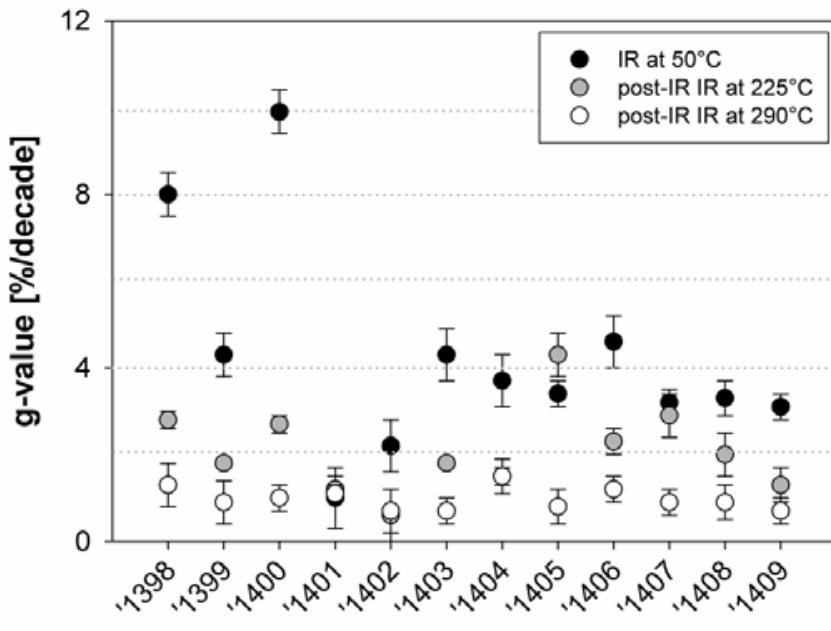

Fig. 10: Comparison of laboratory fading rates [\%/decade] for all samples using the different (post-IR) IRSL signals. Lowest fading rates are observed for the post-IR IRSL measurements at $290^{\circ} \mathrm{C}$. For details about laboratory fading measurements see text.

Abb.10: Vergleich der experimentell ermittelten Fading-Raten [\%/Dekade] für alle Proben bei Anwendung der verschiedenen (post-IR) IRSL-Signale. Die geringsten Fading-Raten wurden für das post-IR IRSL-Signal bei $290^{\circ} \mathrm{C}$ gemessen.

ment with the age of sample 1402 (unit PII-3), which also originates from below the 'Paudorfer Bodenbildung' (Fig. 3) and was dated to $187 \pm 12 \mathrm{ka}$. The individual soils of the 'Paudorfer Bodenbildung' might thus have formed during sub-stages of MIS 5. Originally the formation of the soil was attributed to a Würmian interstadial by GöTZINGER (1936); at that time it was not recognised as being a pedocomplex. LOŽEK (1976) revised the attribution of GöTZINGER (1936), because an interglacial mollusc fauna was found in the lowermost part of the 'Paudorfer Bodenbildung', i.e. the lower part of this pedocomplex developed most likely during MIS 5e. This is in agreement with our dating results and with the TL results of ZöLLER et al. (1994), who state that their age of $103 \pm 11$ ka below the 'Paudorfer Bodenbildung' at its type locality should be regarded as a minimum age. The attribution of the 'Paudorfer Bodenbildung' to MIS 3 as suggested by Noll et al. (1994) can clearly be dismissed. At profile Paudorf II, the BC horizon, i.e. the weakly developed palaeosol (unit PII-8, Fig. 3) is younger than $189 \pm 16$ ka (sample 1401); a correlation with other soils in this area remains unclear and needs further investigations. For the underlying pedocomplex (unit PII-10), which has been correlated with the 'Göttweiger Verlehmungszone', it can only be concluded that it has to be older than $189 \pm 16 \mathrm{ka}$. Hence further investigations are needed to address the question whether this soil is equivalent to the 'Göttweiger Verlehmungszone', which is dated to $>350 \mathrm{ka}$ (sample 1405; minimum age based on $2{ }^{*} \mathrm{D}_{0}$ for post-IR IRSL at $290^{\circ} \mathrm{C}$; Wintle \& MURray, 2006) at its type locality in Göttweig/Furth (Fig. 4a). Originally the 'Göttweiger Verlehmungszone' (unit GI-4) was attributed to MIS 5e (GötZINGER, 1936), but ZöLLER et al. (1994) observed natural TL signals from above and below the 'Göttweiger Verlehmungszone' close to saturation and concluded that their ages of $\sim 200$ ka have to be interpreted as minimum ages. Furthermore, the alle/Ile ratio of Pupilla shells taken from loess immediately above the 'Göttweiger Verlehmungszone' soil is too high to be from penultimate glacial loess (ZöLLER et al., 1994). SMOLíkovÁ (1994) suggest that this pedocomplex is perhaps of Holsteinian age, which at present is correlated with MIS 11 or MIS 9. Our minimum age is consistent with these findings. This age model is also supported by the dating of the loess sample 1407 above the tephra, $300 \mathrm{~m}$ upslope of Section I, which yielded $\geq 300 \mathrm{ka}$; the loess sample 1406 above the tephra was dated to $173 \pm 40 \mathrm{ka}$, clearly showing a hiatus in the sequence. It has to be noted that the tephra, if found in other sequences, might be a useful Middle Pleistocene marker, dated to $\geq 300 \mathrm{ka}$.

At Section II (Göttweig/Aigen; Fig. 3b) the loess unit GII1 above the reworked loess (unit GII-2) and the pedocomplex (unit GII-3) is dated to $34 \pm 3 \mathrm{ka}$ (sample 1408), and is thus in good agreement with ZöLLER et al.'s (1994) TL results of $28 \pm 3 \mathrm{ka}$. They dated the loess below the pedocomplex to $107 \pm 10 \mathrm{ka}$ (regenerative dose method) and $119 \pm 13 \mathrm{ka}$ (additive dose method) and concluded that the soil formation lasted about $90 \mathrm{ka}$. Even though we have obtained a very similar age of $124 \pm 25 \mathrm{ka}$ for the loess from below the soil (sample 1409), we argue that there is certainly some break in the sedimentary record, rather than a long pedogenetic phase, because the pedocomplex is clearly eroded (indicated by the lack of an A horizon and a covering of soil sediment). Nevertheless, the age suggests that the pedocomplex exposed in Göttweig/Aigen corresponds with the 'Paudorfer Bodenbildung' at its type locality (GöTZINGER, 1936).

\section{Conclusions}

We have used two recently suggested post-IR IRSL dating protocols (BUyLAERT et al., 2009; THIEL et al., 2011a) to compare ages and so unravel the chronostratigraphy of prominent palaeosols in Lower Austria. In addition, we have compared the fading rates and ages derived from post-IR IRSL dating with IRSL at $50^{\circ} \mathrm{C}$ (measured as part of the post-IR IRSL measurements at $225^{\circ} \mathrm{C}$ ).

The samples behave satisfactorily in the two post-IR IRSL SAR protocols, i.e. recycling ratios and dose recoveries are close to unity and recuperation is well below $5 \%$ for most of the samples. The lowest laboratory fading rates are observed using the post-IR IRSL signal at $290^{\circ} \mathrm{C}$, followed by post-IR IRSL at $225^{\circ} \mathrm{C}$, and fading rates for IR at $50^{\circ} \mathrm{C}$ tend to be the highest. The fading rates of the post-IR IRSL at $290^{\circ} \mathrm{C}$ are in most cases below 1\%/decade, and based on the observations of THIEL et al. (2011a) we conclude that fading for this signal is probably negligible over geological time and so we do not attempt any fading correction of this signal. Good agreement between the ages derived from the post-IR IRSL signals and those from IRSL at $50^{\circ} \mathrm{C}$ on young samples shows that the post-IR IRSL signals are bleachable. Nevertheless it remains unclear whether the residual dose observed following laboratory bleaching, or some part of it, needs to be subtracted from the $\mathrm{D}_{\mathrm{e}}$. The fading corrected ages for post-IR IRSL at $225^{\circ} \mathrm{C}$ are in generally good agreement with the uncorrected ages for post-IR IRSL at $290^{\circ} \mathrm{C}$. Both post-IR IRSL signals could be used for dating; we prefer the post-IR IRSL at $290^{\circ} \mathrm{C}$ because no fading correction seems to be needed, and so there are no dose/age limitations imposed by the use of a correction model. However, one $290^{\circ} \mathrm{C}$ age appeared significantly overestimated in the stratigraphical context, which has to be a matter of future investigations. 

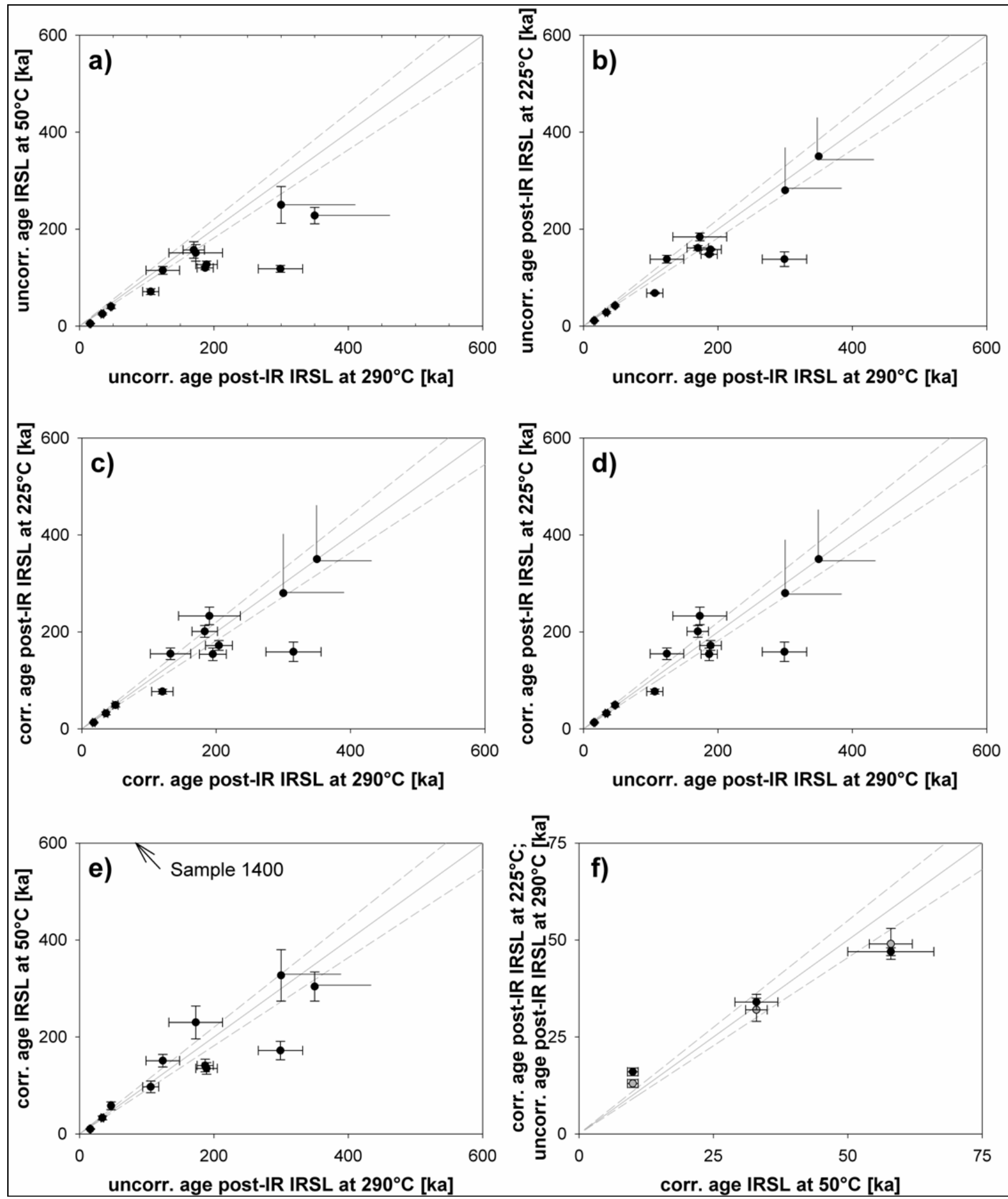

Fig. 11: Comparison of ages for all samples using the different (post-IR) IRSL signals. The ages shown are without subtraction of the residuals. a) Fading uncorrected ages for IRSL at $50^{\circ} \mathrm{C}$ against fading uncorrected ages for post-IR IRSL at $290^{\circ} \mathrm{C}, b$ ) fading uncorrected ages for post-IR IRSL at $225^{\circ} \mathrm{C}$ against fading uncorrected ages for post-IR IRSL at $290^{\circ} \mathrm{C}$, c) fading corrected ages for post-IR IRSL at $225^{\circ} \mathrm{C}$ against fading corrected ages for post-IR IRSL at $290^{\circ} \mathrm{C}$, d) fading corrected ages for post-IR IRSL at $225^{\circ} \mathrm{C}$ against fading uncorrected ages for post-IR IRSL at $290^{\circ} \mathrm{C}$, e) fading corrected ages for IRSL at $50^{\circ} \mathrm{C}$ against fading uncorrected ages for post-IR IRSL at $290^{\circ} \mathrm{C}$, and f) young ( $<70 \mathrm{ka}$ ) fading corrected ages for post-IR IRSL at $225^{\circ} \mathrm{C}$ (grey circles) and fading uncorrected ages for post-IR IRSL at $290^{\circ} \mathrm{C}$ (black circles) against corrected ages for IRSL at $50^{\circ} \mathrm{C}$, to show the relative bleachability of the post-IR IRSL signals. Minimum ages are shown with open error bars. Solid line is a 1:1 line, and dashed lines represent $\pm 10 \%$.

Abb. 11: Vergleich der Alter für alle Proben unter Verwendung der verschiedenen (post-IR) IRSL-Signale. Die angeführten Alter sind ohne Subtraktion des Restsignals. a) Nicht-korrigierte Alter für IRSL bei $50^{\circ} \mathrm{C}$ gegen nicht-korrigierte post-IR IRSL-Alter bei $290^{\circ} \mathrm{C}$, b) nicht-korrigierte post-IR IRSL-Alter bei $225^{\circ} \mathrm{C}$ gegen nicht-korrigierte post-IR IRSL-Alter bei $290^{\circ} \mathrm{C}$, c) korrigierte post-IR IRSL-Alter bei $225^{\circ} \mathrm{C}$ gegen korrigierte post-IR IRSL-Alter bei $290^{\circ} \mathrm{C}, d$ ) korrigierte post-IR IRSL-Alter bei $225^{\circ} \mathrm{C}$ gegen nicht-korrigierte post-IR IRSL-Alter bei $290^{\circ} \mathrm{C}$, e) korrigierte Alter für IRSL bei $50^{\circ} \mathrm{C}$ gegen nicht-korrigierte post-IR IRSL-Alter bei $290^{\circ} \mathrm{C}$, und f) junge (<70 ka) korrigierte Alter für post-IR IRSL bei $225^{\circ} \mathrm{C}$ (graue Punkte) und nicht-korrigierte Alter für post-IR IRSL bei $290^{\circ} \mathrm{C}$ (schwarze Punkte) gegen korrigierte IRLS-Alter bei $50^{\circ} \mathrm{C}$, um die relative Zurücksetzung der post-IR IRSL-Signale zu zeigen. Minimale Alter sind mit offenen Fehlerbalken gezeigt. Die durchgezogene Linie zeigt die 1:1-Linie, und die gestrichelten Linien repräsentieren $\pm 10 \%$. 
We assign the 'Paudorfer Bodenbildung' at its type locality in Paudorf to MIS 5. It is furthermore very likely that the pedocomplex in Göttweig/Aigen developed during the same time and can hence be correlated with the 'Paudorfer Bodenbildung'. The same is true for the pedocomplex exposed in Joching. The absolute age of the 'Göttweiger Verlehmungszone' remains unclear due to saturation of the sample above this soil; the saturation implies an age >350 ka for the 'Göttweiger Verlehmungszone'. The discontinuities in sedimentation observed at these sites are hence significant. It has to be noted that sampling at higher resolution is needed to draw final conclusions on the extent of the discontinuities. The correlation of Lower Austrian loess deposits and their interleaved palaeosols thus remains problematic. Advances in absolute dating techniques such as post-IR IRSL dating are of importance to address the many remaining open questions on loess stratigraphy in the future.

\section{Acknowledgements}

This study was supported by the Leibniz Pakt Project for Research and Innovation 2008-2010. We are indebted to Bodo Damm for assistance during field work and to Sonja Riemenschneider for support in the laboratory. We thank Kristina Thomsen and Mayank Jain for fruitful discussions on post-IR IRSL dating. Sébastien Huot is thanked for the Excel macros which were used to calculate fading rates in a fast and elegant manner.

\section{References}

Adamiec, G. $\mho$ Aitken, M.J. (1998): Dose-rate conversion factors: update. - Ancient TL, 16: 37-50.

Aitken, M.J. (1985): Thermoluminescence Dating. London (Academic Press).

Aitken, M.J. (1998): An Introduction to Optical Dating. The Dating of Quaternary Sediments by the Use of Photon-stimulated Luminescence. Oxford (Oxford University Press).

Auclair, M., Lamothe, M. \& Huot, S. (2003): Measurement of anomalous fading for feldspar IRSL using SAR. - Radiation Measurement, 37: 487-492.

BAyer, J. (1927): Der Mensch im Eiszeitalter; I. und II. Teil. Wien (Deutike).

Bøtter-Jensen, L., Andersen, C.E., Duller, G.A.T. \& Murray, A. S. (2003): Developments in radiation, stimulation and observation facilities in luminescence measurements. - Radiation Measurements, 37: 535-541.

Buylaert, J.P., Vandenberghe, D., Murray, A.S., Huot, S., De Corte, F. ひ VAN DEN HAUTE, P. (2007): Luminescence dating of old (>70 ka) Chinese loess: A comparison of single aliquot OSL and IRSL ages. -Quaternary Geochronology, 2: 9-14.

Buylaert, J.P., Murray, A.S., Thomsen, K.J. \& Jain, M. (2009): Testing the potential of an elevated temperature IRSL signal from K-feldspar. - Radiation Measurements, 44: 560-565.

Buylaert, J.P., Huot, S., Murray, A.S. ¿ VAN DEN haute, P. (2011). Infrared stimulated luminescence dating of an Eemian (MIS 5e) site in Denmark using K-feldspar. - Boreas, 40: 46-56.

Duller, G.A.T. \& Wintle, A.G. (1991): On infrared stimulated luminescence at elevated temperatures. - Nuclear Tracks and Radiation Measurements, 18: 379-384.

FINK, J. (1976): Exkursion durch den österreichischen Teil des nördlichen Alpenvorlandes und den Donauraum zwischen Krems und Wiener Pforte. Erweiterter Führer zur Exkursion aus Anlass der 2. Tagung der IGCPProjektgruppe „Quaternary Glaciations in the Northern Hemisphere. - Mitteilungen der Kommission für Quartärforschung der Ósterreichischen Akademie der Wissenschaften,1: 113 pp.

Frechen, M., Horváth, E. ¿ GÁBrIs, G. (1997): Geochronology of Middle to Upper Pleistocene Loess Sections in Hungary. - Quaternary Research, 48: 291-312.
Frechen, M., Schweitzer, U. \& Zander, A. (1996): Improvements in sample preparation for the fine grain technique. - Ancient TL, 14: 15-17.

GöTzINGER, G. (1936): Das Lößgebiet um Göttweig und Krems an der Donau. Führer für die Quartär-Exkursionen in Österreich 1, pp. 1-11.

Haesaerts, P., Damblon, F., Bachner, M. \& Trnka, G. (1996): Revised stratigraphy and chronology of the Willendorf II sequence, Lower Austria. - Archaeologia Austriaca, 80: 25-42.

Havliček, P., HolÁsek, O., SmolíkovÁ, L. ひ Roetzel, R. (1998): Zur Entwicklung der Quartärsedimente am Südostrand der Böhmischen Masse in Niederösterreich. - Jahrbuch der Geologischen Bundesanstalt, 141: $51-72$.

Head, M.J., Gibbard, P.L. \& SAlvador, A. (2008): The Quaternary: its character and definition. - Episodes, 31: 234-238.

Huntley, D.J. \& Clague, J.J. (1996): Optical dating of tsunami-laid sands. Quaternary Research, 46: 127-140.

HuntLey, D.J. \& LAMOTHE, M. (2001): Ubiquity of anomalous fading in Kfeldspars and the measurement and correction for it in optical dating. - Canadian Journal of Earth Science, 38: 1093-1106.

Kars, R.H., Wallinga, J. \& Cohen, K.M. (2008): A new approach towards anomalous fading correction for feldspar IRSL dating - tests on samples in field saturation. - Radiation Measurements, 43: 786-790.

Kunz, A., Frechen, M., Ramesh, R. $\mho$ Urban, B. (2010): Revealing the coastal event-history of the Andaman Islands (Bay of Bengal) during the Holocene using radiocarbon and OSL dating. - International Journal of Earth Science (Geologische Rundschau), 8: 1741-1761.

Lai, Z.P., Zhang, W.G., Chen, X., Jia, Y. L., Liu, X.J., Fan, Q.S. \& Long, H. (2010): OSL chronology of loess deposits in East China and its implications for East Asian monsoon history. - Quaternary Geochronology, 5: $154-158$.

LAmothe, M. \& Auclair, M. (1999): A solution to anomalous fading and age shortfalls in optical dating of feldspar minerals. - Earth and Planetary Science Letters, 171: 319-323.

Lamothe, M., Auclair, M., Hamzaoui, C. \& Huot, S. (2003): Towards a prediction of long-term anomalous fading of feldspar IRSL. - Radiation Measurements, 37: 493-498.

LožEK, V. (1976): Stop 8a/3: Hohlweg Aigen, Malakologie. In: FInK, J. (ed.): Exkursion durch den österreichischen Teil des nördlichen Alpenvorlandes und den Donauraum zwischen Krems und Wiener Pforte. Erweiterter Führer zur Exkursion aus Anlass der 2. Tagung der IGCPProjektgruppe „Quaternary Glaciations in the Northern Hemisphere - Mitteilungen der Kommission für Quartärforschung der Österreichischen Akademie der Wissenschaften, 1: 72-75.

Murray, A.S. \& Wintle, A.G. (2000): Luminescence dating of quartz using an improved single-aliquot regenerative-dose protocol. - Radiation Measurements, 32: 57-73.

Murray, A.S. \& Wintle, A.G. (2003): The single aliquot regenerative dose protocol: potential for improvements in reliability. - Radiation Measurements, 37: 377-381.

Murray, A.S., Buylaert, J.P., Thomsen, K.J. \& Jain, M. (2009): The Effect of Preheating on the IRSL Signal from Feldspar. - Radiation Measurements, 44: 554-559.

Noll, M., Leitner-Wild, E. \& Hille, P. (1994): Thermoluminescence dating of loess deposits at Paudorf, Austria. - Quaternary Geochronology (Quaternary Science Reviews), 13: 473-476.

Novothny, Á., Horváth, E. \& Frechen, M. (2002): The loess profile of Albertirsa, Hungary - Improvements in loess stratigraphy by luminescence dating. - Quaternary International, 95-96: 155-163.

Novothny, Á., Frechen, M., Horváth, E., Bradák, B., Oches, E. A., McCoy, W. D. \& Stevens, T. (2009): Luminescence and amino acid racemisation chronology of the loess-paleosol sequence at Süttő, Hungary. - Quaternary International, 198: 62-76.

Novothny, Á., Frechen, M., Horváth, E., Krbetschek, M. \& Tsuкамото, S. (2010): Infrared stimulated luminescence and radiofluorescence dating of aeolian sediments from Hungary. - Quaternary Geochronology, 5: 114-119.

Poolton, N.R.J., Ozanyan, K.B., Wallinga, J., Murray, A.S. \& BøtterJENSEN, L. (2002): Electrons in feldspar II: a consideration of the influence of conduction band-tail states on luminescence processes. Physics and Chemistry in Minerals, 29: 217-225.

Prescott, J.R. \& Hutton, J.T. (1994): Cosmic ray contributions to dose rates for luminescence and ESR dating: large depths and long-term variations. - Radiation Measurements, 23: 497-500.

ReEs-Jones, J. (1995): Optical dating of young sediments using fine-grain quartz. - Ancient TL, 13: 9-14.

Reimann, T., Tsukamoto, S., Naumann, M. \& Frechen, M., (2011). The potential of using K-rich feldspars for optical dating of young coastal 
sediments - A test case from Darss-Zingst peninsula (southern Baltic Sea coast). - Quaternary Geochronology, 6: 207-222.

RoBerts, H.M. (2008): The development and application of luminescence dating to loess deposits: a perspective on the past, present and future. - Boreas, 37: 483-507.

SMolíkovÁ, L. (1994): Paleopedologický výzkum významných lokalit Paudorf, Göttweig, Krems a Stranzendorf. Zpr. Geol. Výzk. v Roce, 80.

SPOONER, N.A (1994): The anomalous fading of infra-red stimulated luminescence from feldspars. - Radiation Measurements, 23: 625-632.

Thiel, C., Coltorti, M., Tsukamoto, S. \& Frechen, M. (2010): Geochronology for some key sites along the coast of Sardinia (Italy). Quaternary International, 222: 36-47.

Thiel, C., Buylaert, J.-P., Murray, A.S., Terhorst, B., Hofer, I. Tsukamoto, S. \& Frechen, M. (2011a): Luminescence dating of the Stratzing loess profile (Austria) - Testing the potential of an elevated temperature post-IR IRSL protocol. - Quaternary International, 234: 23-31.

Thiel, C., Terhorst, B., Jaburová, I., Buylaert, J.-P., Murray, A.S., Fladerer, F.A., Damm, B., Frechen, M. \& Ottner, F. (2011b): Sedimentation and erosion processes in Middle to Late Pleistocene sequences exposed in the brickyard of Langenlois/Lower Austria. Geomorphology, in press (doi: 10.1016/j.geomorph.2011.02.011).

Thiel, C., Buylaert, J.-P., Murray, A.S. \& Tsukamoto, S. (accepted): On the applicability of post-IR IRSL dating to Japanese loess. Geochronometria.

Thomsen, K.J., Bøtter-Jensen, L., Denby, P.M., Moska, P. \& Murray, A.S. (2006): Developments in luminescence measurement techniques. - Radiation Measurements, 41: 768-773.
Thomsen, K.J., Murray, A.S., Jain, M. ひ Bøtter-Jensen, L. (2008): Laboratory fading rates of various luminescence signals from feldspar-rich sediment extracts. - Radiation Measurements, 43: 1474-1486.

Thomsen, K.J., Murray, A.S. \& JAIn, M. (2011): Stability of IRSL signals from sedimentary K-feldspar samples. - Geochronometria, 38: 1-13.

Wallinga, J., Bos, A.J.J., Dorenbos, P., Murray, A.S. \& Schokker, J. (2007): A test for anomalous fading correction in IRSL dating. - Quaternary Geochronology, 2: 216-221.

WANG, X.L., Lu, Y.C. \& WintLE, A. G. (2006): Recuperated OSL dating of fine-grained quartz in Chinese loess. - Quaternary Geochronology, 1: 89-100.

Watanuki, T., Murray, A.S. \& Tsukamoto, S. (2005): Quartz and polymineral luminescence dating of Japanese loess over the last $0.6 \mathrm{Ma}$ Comparison with an independent chronology. - Earth and Planetary Science Letters, 240: 774-789.

Wintle, A.G. (1973): Anomalous Fading of Thermo-luminescence in Mineral Samples. - Nature, 245: 143-144.

Wintle, A.G. \& Murray, A.S. (2006): A review of quartz optically stimulated luminescence characteristics and their relevance in single-aliquot regeneration dating protocols. -Radiation Measurements, 41: 369-391.

Zöller, L., Oches, E.A. \& McCoy, W.D. (1994): Towards a revised chronostratigraphy of loess in Austria with respect to key sections in the Czech Republic and in Hungary. - Quaternary Geochronology (Quaternary Science Reviews), 13: 465-472. 